\title{
Floristic Composition, Diversity and Structure of the Rainforest in the Mayoko District, Republic of Congo
}

\section{Margaretha W. van Rooyen1,2, Noel van Rooyen ${ }^{2,3}$, Edmond S. Miabangana4, Gilbert Nsongola ${ }^{4}$, Caroline Vasicek Gaugris ${ }^{2,5}$, Jérôme Y. Gaugris ${ }^{2,5 *}$}

\author{
${ }^{1}$ Department of Plant \& Soil Sciences, University of Pretoria, Pretoria, South Africa \\ ${ }^{2}$ FLORA FAUNA \& MAN, Ecological Services Ltd., Tortola, British Virgin Islands \\ ${ }^{3}$ Ekotrust, Somerset West, South Africa \\ ${ }^{4}$ Centre d'Etude sur les Ressources Végétales, Herbier National du Congo, Brazzaville, Republic of Congo \\ ${ }^{5}$ Centre for African Ecology, School of Animal, Plant and Environmental Sciences, University of the Witwatersrand, \\ Johannesburg, South Africa \\ Email: *jeromegaugris@florafaunaman.com
}

How to cite this paper: van Rooyen, M. W., van Rooyen, N., Miabangana, E. S., Nsongola, G., Gaugris, C. V., \& Gaugris, J. Y. (2019). Floristic Composition, Diversity and Structure of the Rainforest in the Mayoko District, Republic of Congo. Open Journal of Forestry, 9, 16-69.

https://doi.org/10.4236/ojf.2019.91002

Received: December 17, 2018

Accepted: January 18, 2019

Published: January 21, 2019

Copyright (c) 2019 by author(s) and Scientific Research Publishing Inc. This work is licensed under the Creative Commons Attribution International License (CC BY 4.0).

http://creativecommons.org/licenses/by/4.0/

\section{(c) (i) Open Access}

\begin{abstract}
Botanically, the Mayoko district is known only through anecdotal descriptions made in the colonial era. The present study was undertaken as part of the prerequisite for a mining feasibility study where a benchmark of the floristic composition, diversity and structure of the vegetation was needed to evaluate potential biodiversity offset areas and to guide species selection for post-mining re-vegetation. The study area comprised approximately 160,000 ha and 235 sample sites were surveyed using the Braun-Blanquet method of phytosociology. Diversity of each plant association was expressed in terms of various diversity parameters. Twelve associations were described and mapped. The associations ranged from highly disturbed and degraded to fairly intact forest associations. A wet to dry gradient and permanently inundated to temporary inundated gradient could also be distinguished. The approach followed here proved remarkably robust in illustrating the complexity in a topographically complex region of the Chaillu Massif. The data provided a high level of insight into the possible dynamics of the rainforest and indications as to possible successional pathways. This information provides a better level of understanding of forest structure and evolution potential than studies limited to trees, remote sensing carbon assessments, or time change series.
\end{abstract}

\section{Keywords}

Congo, Diversity, Evenness, Fisher's Alpha, Flora, Phytosociology, Species Richness, Structure, Rainforest, Vegetation Dynamics 


\section{Introduction}

Africa's forests constitute the second largest area of tropical rainforest in the world and cover approximately $20 \%$ of total global tropical rainforest area (Mayaux et al., 2013). In spite of their importance in modulating regional climate (Fisher et al., 2013), acting as significant reservoirs of carbon and biodiversity, regulating flows of large rivers, and supporting the livelihoods of rural people (Malhi et al., 2013a), vast tracts of African tropical rainforest remain poorly studied (Malhi et al., 2013b). In the face of global climate change, with substantial predicted variations in hygrometry and wet season duration, a major question is whether African rainforests will be able to cope with such changes and yet retain their role as carbon and biodiversity sinks (James et al., 2013). Malhi et al. (2013b) contend that African rainforests may have a better chance of surviving changed weather patterns than their counterparts in South America or southeast Asia, a fact supported by the range of variations that these forests appear to have gone through over the past 5000 years (Oslisly et al., 2013). However, such assumptions remain based on broad scale knowledge without in depth assessment of phytosociological assemblages and their likely dynamics, a key aspect in understanding response and resilience of habitats to change and disturbance (Willis et al., 2013).

Because phytosociological analysis of rainforest systems is complex, costly and time consuming (Vande Weghe, 2004), most work in recent years appears to have focussed on carbon related assessments to evaluate African rainforests potential to capture carbon and contribute towards mitigating climate change, yet none of these studies investigated relationships between tree species or relationships with biotic factors within the landscapes in which they occur. Tchouto et al. (2005) highlighted that knowledge on tree diversity was a poor indicator of general biodiversity levels for central African rainforests as it did not provide details on the shrub, herbaceous or epiphytic diversity, which, combined, harboured the majority of the species diversity in such habitats (Corlett \& Primack 2011; Lovett \& Wasser, 2008). Other recent studies on the bush meat trade in Africa (Lindsey et al., 2013) and central African rainforests in particular (Abernethy et al., 2013; Mbete et al., 2011) highlight the risk of large scale ecosystem collapse that may be of greater consequence on rainforest structure and resilience than climate change. Because forests have such a key role as an ecosystem service provider at local, national and global level, it becomes urgent to understand their intrinsic complexity. Of key importance to these questions is the relationships between various levels of vegetation, but also between plants and the fauna that roams the forests, in order to ensure ecosystem services are maintained through understanding of key support functions provided by various functional groups hosted by forests. This task is made more complex, because apart from mapping of broad-scale vegetation classes (at national level, De Wasseige et al., 2014), African rainforests remain poorly understood on local to subregional scales and smaller landscape variations would typically be ignored 
(Tchouto et al., 2005; Pierson et al. 2015). However, there are strong suggestions that local variations may have a significant impact once compounded over larger scales.

The notion of ecosystem service maintenance and sustainable use is also a key aspect in the national development of most countries when energy, transport, mining and forestry management are considered (Damania \& Wheeler, 2015; Edwards et al., 2014; International Finance Corporation Performance Standard 6 Guidance Note, 2012; Hund et al., 2013). Indeed, through international regulations and best practice standards, countries and private sector consortia proposing to develop the resources should aim to ensure that ecosystem services are well understood before operations/development commence, in order to guarantee that natural environment ecosystem services are not damaged through such activities. In most instances, the task of understanding these services is nigh on impossible due to the lack of baseline information and adequate methodological guidance to undertake such evaluations (Gullison et al., 2015). From that viewpoint, the key dimension of ecosystem service delivery is to understand the variations within forest communities (Maguran \& McGill, 2011) and how they influence local to regional levels (Elliot et al., 2013). In the central African rainforest context, the main ecosystem service provider is the forest itself, with its many variations being considered as providers of widely different service levels (Corlett \& Primack, 2011; Lovett \& Wasser, 2008; Grunewald \& Bastian, 2015; Wilson et al., 2016), as has been described on other continents where better levels of information are available.

In the present study, the authors were confronted with a typical "African Rainforest" whereby the study area was known only through vague descriptions made in the colonial era of the Republic of Congo (De Wasseige et al., 2014), with little to no additional information since these times. The Mayoko district in the Niari Department of the southwestern Republic of Congo, is a part of the country known for a wealth of underground resources of interest for the mining sector, but also a key road link between Congo, Gabon and Cameroon further north. The forest descriptions closest to the study area are those from Gautam \& Pietsch (2012) who describe carbon contents of an intact forest, in a national park across the border, in Gabon. The present study was undertaken as part of the prerequisite for a mining feasibility study and a baseline benchmark of the vegetation was needed to provide information on floristic composition and plant diversity for the area. Such information is of critical importance to investigate ecosystem services (Grunewald \& Bastian, 2015) and evaluate potential biodiversity offset areas (Pilgrim et al., 2013), but also to select suitable species for post-mining re-vegetation, in order to promote succession towards a forested state that would approach pre-mining levels of species diversity, structural complexity and service delivery (Elliot et al., 2013).

As there were no definitive methodological guidance sources, the authors used classical phytosociology methodology (Kent, 2012) to tease out the complexity of 
the systems on the basis of landscape relationships and to investigate possible successional linkages between the different units identified. The value of the methods employed is further discussed.

\section{Study Area}

The study area is located in the Mayoko District, Niari Department, Republic of Congo and covered an area of 160,000 ha (Figure 1). The area forms part of the Lope-Chaillu-Louesse landscape of biodiversity importance defined by the Central Africa Regional Program for the Environment (CARPE) of USAID. The importance of the landscape lies in a combination of exceptional biodiversity, biogeographical history (forest-savanna mosaic) and cultural richness. It covers $35,000 \mathrm{~km}^{2}$ and stretches from the centre of Gabon to $50 \mathrm{~km}$ inside the Republic of Congo. It hosts some extraordinary fauna and flora associated with rare forest types (De Wasseige et al., 2012).

The landscape centres on the Chaillu Massif, a mountainous region assumed to have sheltered a key forest refuge for Africa during the Pleistocene, explaining

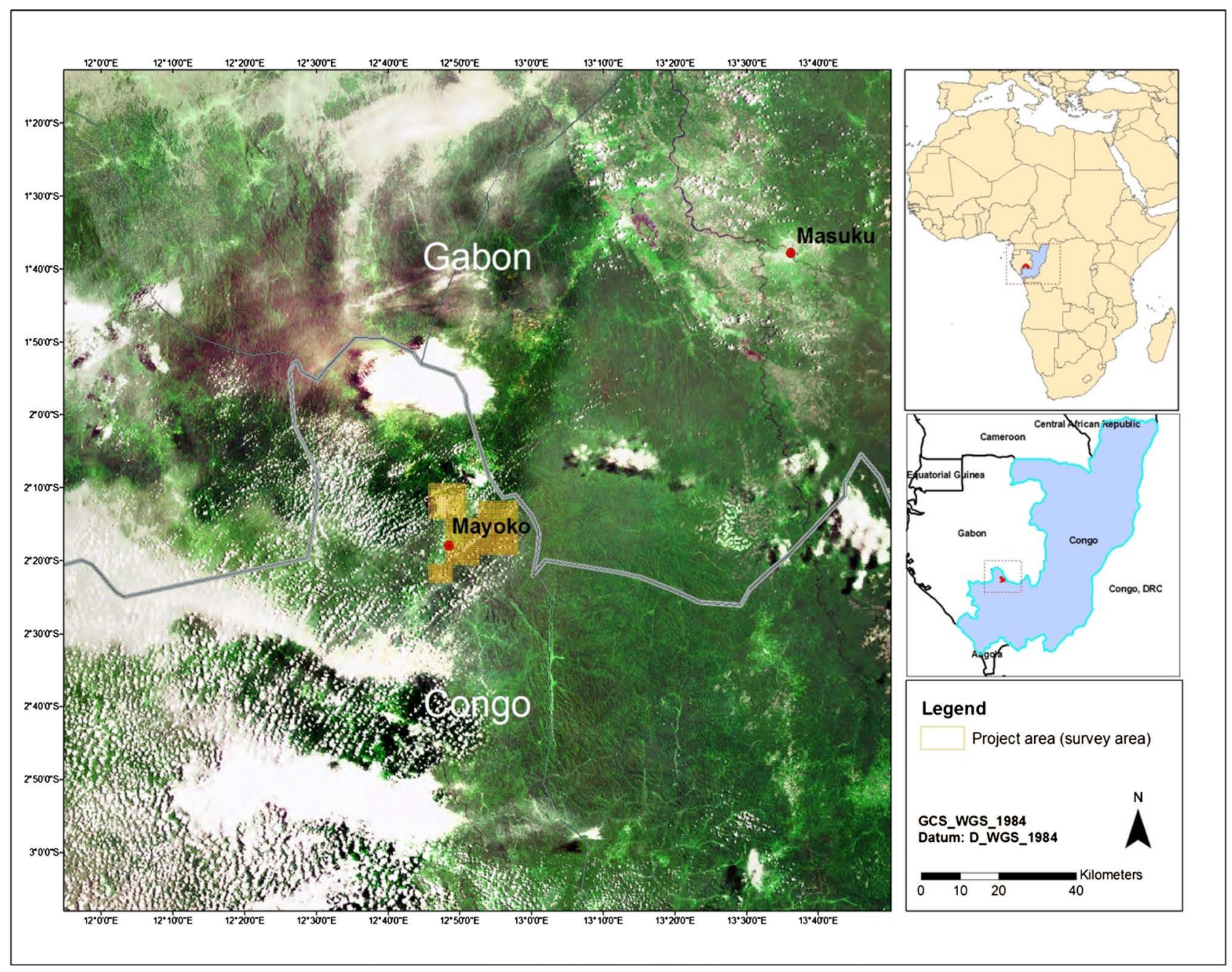

Figure 1. The study area in the Republic of Congo. 
the presence of numerous endemic species. During the last Pleistocene glaciation, the Chaillu Massif foothills were apparently covered with savannas. The landscape is considered to hold the highest densities of large mammals of any tropical forest and some of the region's richest timber stands, it is also home to human communities from more than 15 ethno-linguistic groups (De Wasseige et al., 2012).

In Monts Birougou National Park (70 km distant from the study area), the mean annual precipitation and temperature are $1800 \mathrm{~mm}$ and $22^{\circ} \mathrm{C}$ respectively. The rainy season extends from mid-September to mid-June with a lower rainfall period during December and January. The dry season lasts almost three months from mid-June to mid-September (Gautam \& Pietsch, 2012).

The landscape portion within the Republic of Congo, including the Chaillu Massif, rests on old undifferentiated Archean gneiss dated to 3.2 billion years, interspersed with strands of granites and calco-alkaline or alkaline granitoids 2.6 to 2.9 billion years old (Chatelin, 1968). A ferralitic soil is found throughout the region (Chatelin, 1968).

\section{Methods}

\subsection{Field Methodology}

Site selection was based on a physiographic-physiognomic vegetation map produced after two reconnaissance visits to the site. A multistage, stratified, semi-random sampling approach (Bourgeron et al., 2001) was applied to ensure representativeness of sampling. A total of 235 sample plots were surveyed between 2012 and 2013 across three different seasons. Sample plots were $25 \mathrm{~m} \mathrm{x} 25$ $\mathrm{m}$ as commonly used in tropical forest sampling (Davidar et al., 2007). Vegetation surveys were conducted following the Zurich-Montpellier (Braun-Blanquet) School of total floristic composition (Werger, 1974). An assessment of broad habitat features (topography, aspect, slope, erosion, clay content of the soil, stone/rock cover and drainage) was made at each sample plot. Estimates of the vegetation height and cover were made for each forest and non-forest vegetation structural layer (viz. lower, intermediate, upper and very tall/emergent) for the tree, shrub and herbaceous layers respectively. The height scale is based on vegetation structure within each plot and therefore does not have distinct boundary definitions. Each plot is assessed on the presence of the different structural layers and a height is given for each. Heights were measures with a Nikon $_{\mathrm{TM}}$ "Forestry Pro" Hypsometer. All species within the sample plot were identified and a cover value allocated following the Domin Krajina-scale (Mueller-Dombois \& Ellenberg, 1974). However, in approximately 50 plots only woody species were recorded for a biomass analysis. The floristic data of these 50 plots were analysed together with fully sampled plots. Plant species were identified summarily in the field using the knowledge base of the field experts (E.S. Miabangana and G. Nsongola), but a specimen of each plant encountered in the plots was also taken, placed in a plant press and checked against available field guides in the evening of the field day for further confirmation. Once full, the 
plant presses were then placed in a field oven to dry all the collected specimens. A further verification of the plant identification was made in the Herbarium against reference collection specimens at the "Centre d'Etudes sur les Ressources Végétales" (CERVE) in Brazzaville.

\subsection{Mapping Methodology}

Mapping tropical forests is a highly complex task and hand-mapping often proves unsuccessful (Newton, 2007). The mapping process therefore followed a modelling approach using the plant association type corresponding to each survey site and their environmental parameters extracted from the various GIS layers, notably: heatload (includes slope and aspect); wetness index; elevation; landform and distance from flood zone. A statistical model resting on fuzzy mathematical theory was created to predict a plant association's likelihood of occurrence in the landscape. The method is described fully in Gaugris et al. (in prep).

\subsection{Vegetation Analysis}

Species accumulation curves (SAC) for all data points were generated using Estimates S (version 9) with 100 randomizations (Colwell, 2013). Curves were generated for the full data set and for the large plant assemblages, which were identified. Sampling sufficiency was determined by establishing whether the point had been reached where a line representing one new sample adding one new species was tangent to the curve (Brewer \& McCann, 1982). Moreno \& Halffter (2000) proposed that a satisfactory level of completeness would have been attained if $90 \%$ of the total fauna (flora in this study) predicted by their models would have been reached. Their model is based on the Michaelis-Menten equation (Soberôn \& Llorente, 1993) and therefore Michaelis-Menten curve-fitting by Estimates S (Raaijmakers, 1987) was also used in this study to determine sampling sufficiency.

Floristic data Classification was done with the TURBOVEG and JUICE computer programs (Hennekens \& Schaminee, 2001; Tichy, 2002). To improve separation into groups an Incremental Sum of Squares (ISS) cluster analysis was run in SYN-TAX 2000 (Podani, 2001). For the ISS and Principal Coordinates Analysis (PCoA) ordinations, cover/abundance values were converted to percentages (Van der Maarel, 2007) and the percentage values standardised using a natural logarithmic $\left(\log _{\mathrm{e}}\right)$ standardisation. The Bray-Curtis measure (Podani, 2001) was applied. The clusters obtained through initial ISS were each subject to a further ISS cluster analysis to refine separation.

The table of sample plots against species was further refined using Braun-Blanquet tabulation procedures (Werger, 1974) to produce a hierarchical classification. The full differential table is available from the corresponding author (jeromegaugris@florafaunaman.com), however, the synoptic table is provided as supplementary material (Appendix A).

Vegetation structure was analysed by calculating a mean height and canopy 
cover value for each stratum. Species richness, evenness, Shannon-Wiener ( $\left.\mathrm{H}^{\prime}\right)$ and the inverse Simpson index of diversity were computed per plot in PCOrd 6 (McCune \& Grace, 2002; McCune \& Mefford, 2011) and a mean per association calculated. Additionally, Fisher's alpha, Shannon-Wiener, exponent of Shannon-Wiener and inverse Simpson index of diversity were computer in Estimates $\mathrm{S}$ for each association as a whole.

Species lists for each association were compared to the classification of species into pioneer, young secondary, old secondary and primary species based on pollen data (Lebamba et al., 2009). A ratio of these different types of species was calculated to provide an indication of the successional state of the forest. It has to be noted however, that pollen data classification is not available for all species and these ratios should not be regarded as an exact reflection of the association's successional status.

\section{Results}

\subsection{Classification}

Twelve plant associations (A1 - A12) and 21 subassociations were distinguished (supplementary material Appendix B). The ISS cluster analysis of the floristic data of all plots revealed three clusters and this division was supported by the PCoA of all plots (Figure 2). Within cluster 1 (Figure 3) the associations could
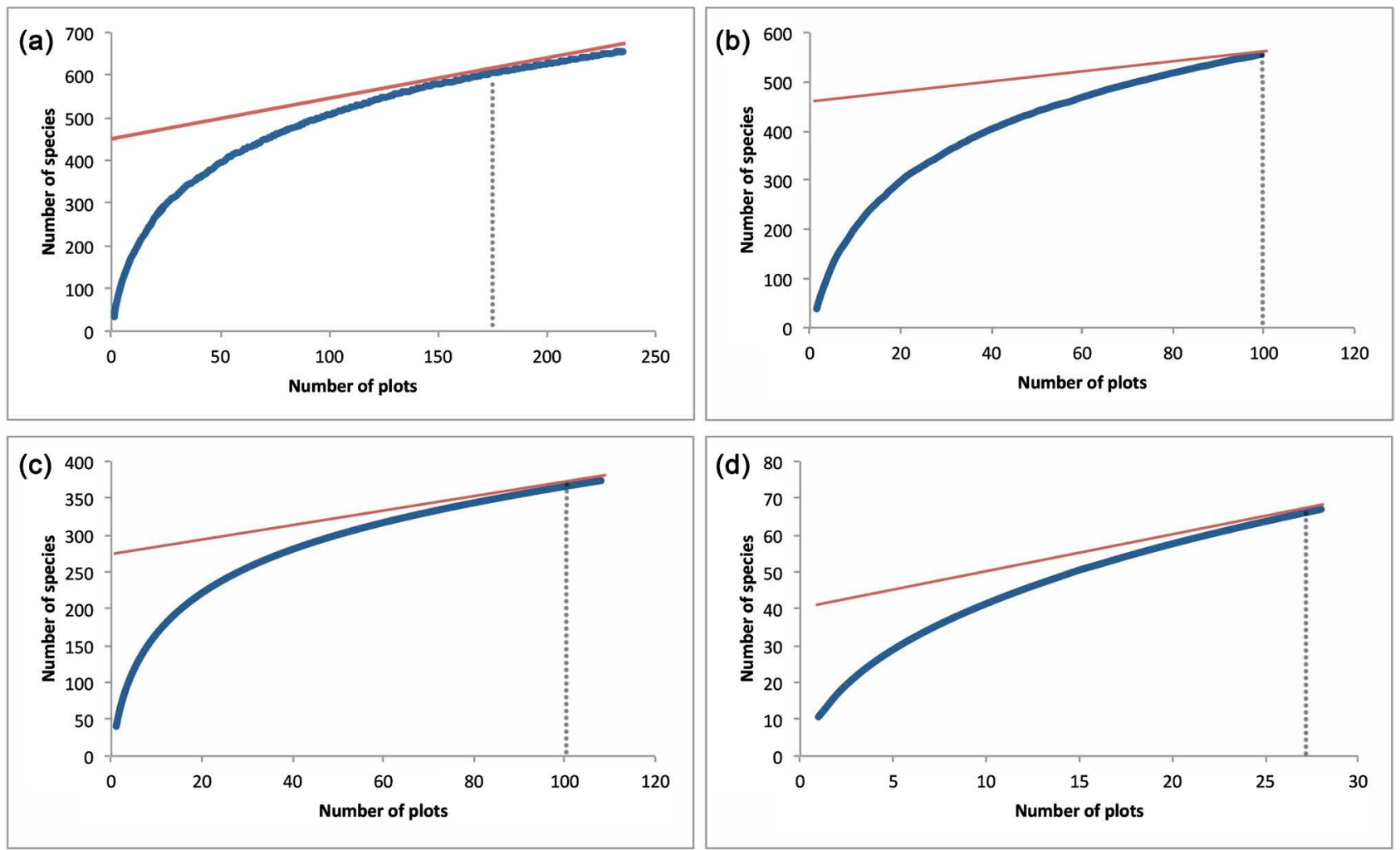

Figure 2. (a) Species accumulation curve (SAC - curved line) performed on all plant species encountered during the field work effort (b) SAC for cluster 1; (c) SAC for cluster 2; and (d) SAC for cluster 3. The fine line indicates the point where a line representing one new sample adding one new species is tangent to the curve. 


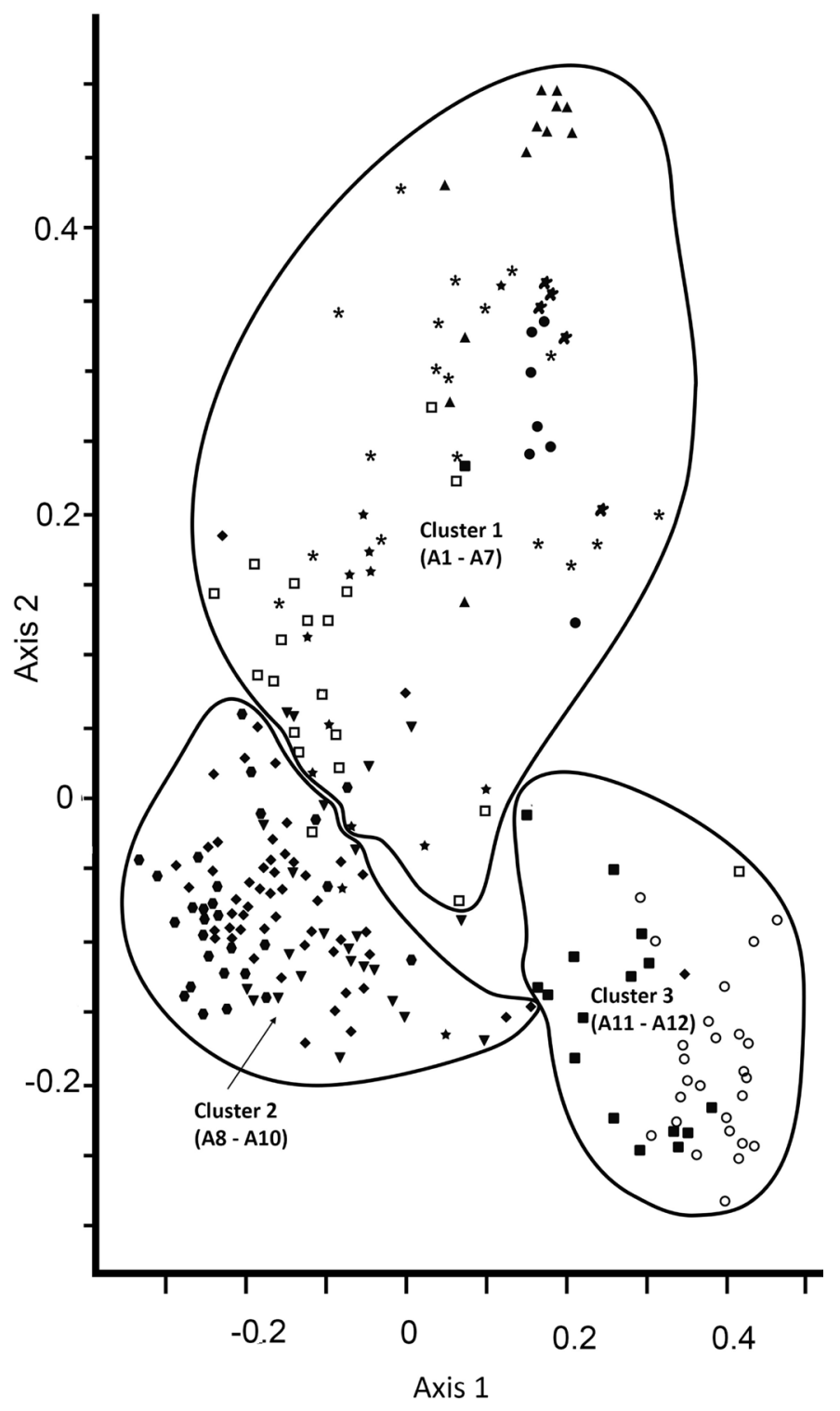

Figure 3. Principal Coordinate Analysis of the full floristic data set showing a clear separation into three clusters. The symbols represent each of the associations identified from A1 to A12, details for the symbols are presented in Figures 4-6 hereafter.

be clearly delineated on the ordination diagram with $\mathrm{A} 1$ in the centre of the ordination space and A2 - A4 separated from A5 - A7 on axis 1. Within the second (Figure 4) and third clusters (Figure 5) the associations were also well separated.

\subsection{Species Accumulation Curves}

A total of 646 plant taxa, representing 103 families, were identified in the 235 sample plots surveyed. This total number of species represents $98 \%$ of the Michaelis-Menten richness estimator. The plant species accumulation curve for all surveys (Figure 6) was tangent to the line representing 1 species added for one plot added after approximately 170 sites had been visited, a number of sur- 
vey sites that corresponds to $91 \%$ of species sampled.

The Michaelis-Menten estimator indicated that $89 \%, 99 \%$ and $85 \%$ of the species had been captured by the sampling effort for clusters 1, 2 and 3 respectively. The point where a line representing one new sample adding one new species was tangent to the curve indicated adequate sampling for clusters 2 and 3 and marginal sufficiency for cluster 1 .

The mean frequency of occurrence of plant species identified was 5.2\% ( $\mathrm{SE}=$ $0.36 \%$; median $=1.7 \%)$. A large number of species $(28 \%$ of species, frequency $0.43 \%)$ were encountered only once during the survey effort. Only six species occurred in more than $50 \%$ of plots visited, with Plagiostyles africana being the most frequent species. Only 42 species had frequencies of occurrence greater

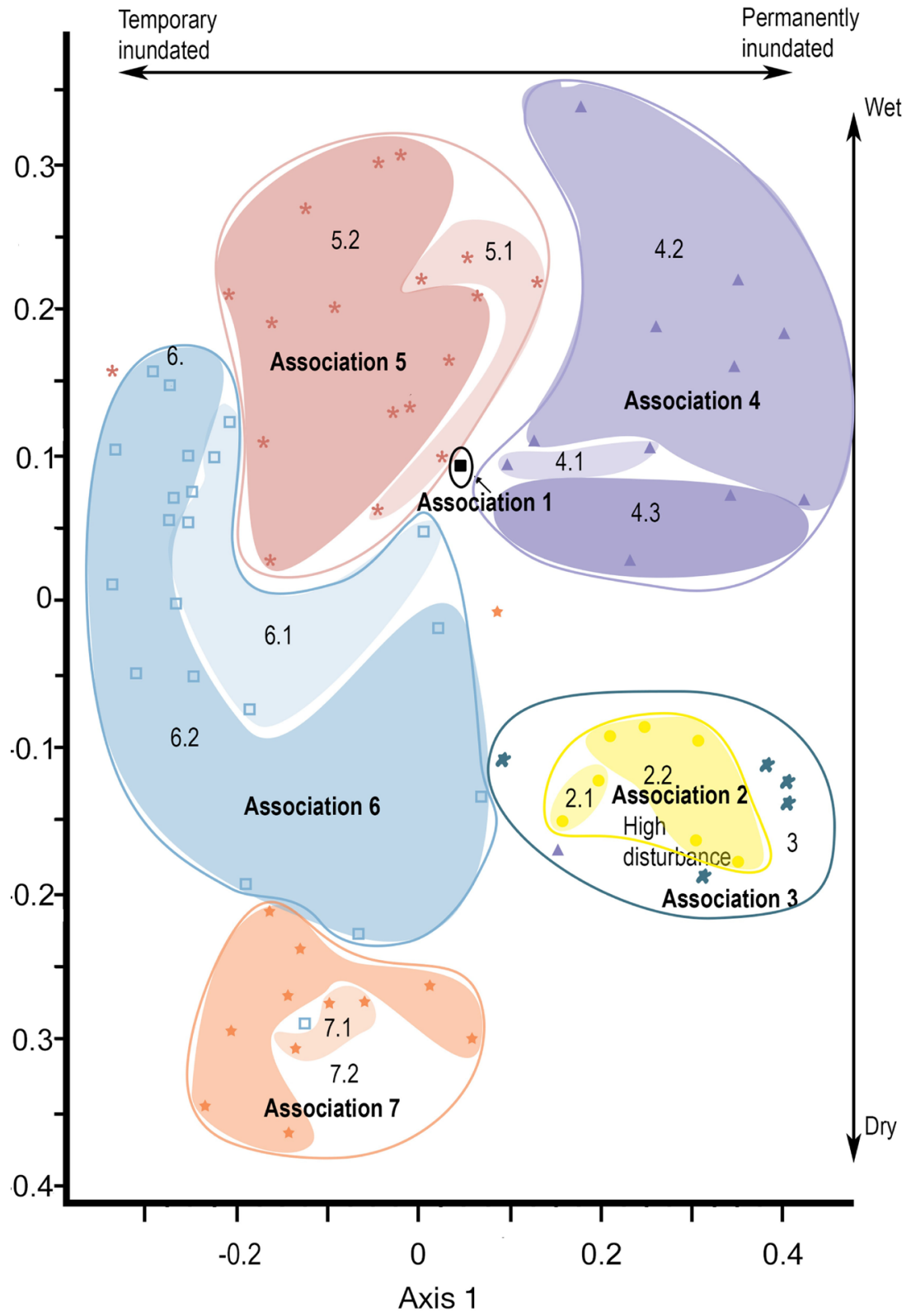

Figure 4. Principal Coordinate Analysis of the floristic data of the cluster 1, associations 1-7. 


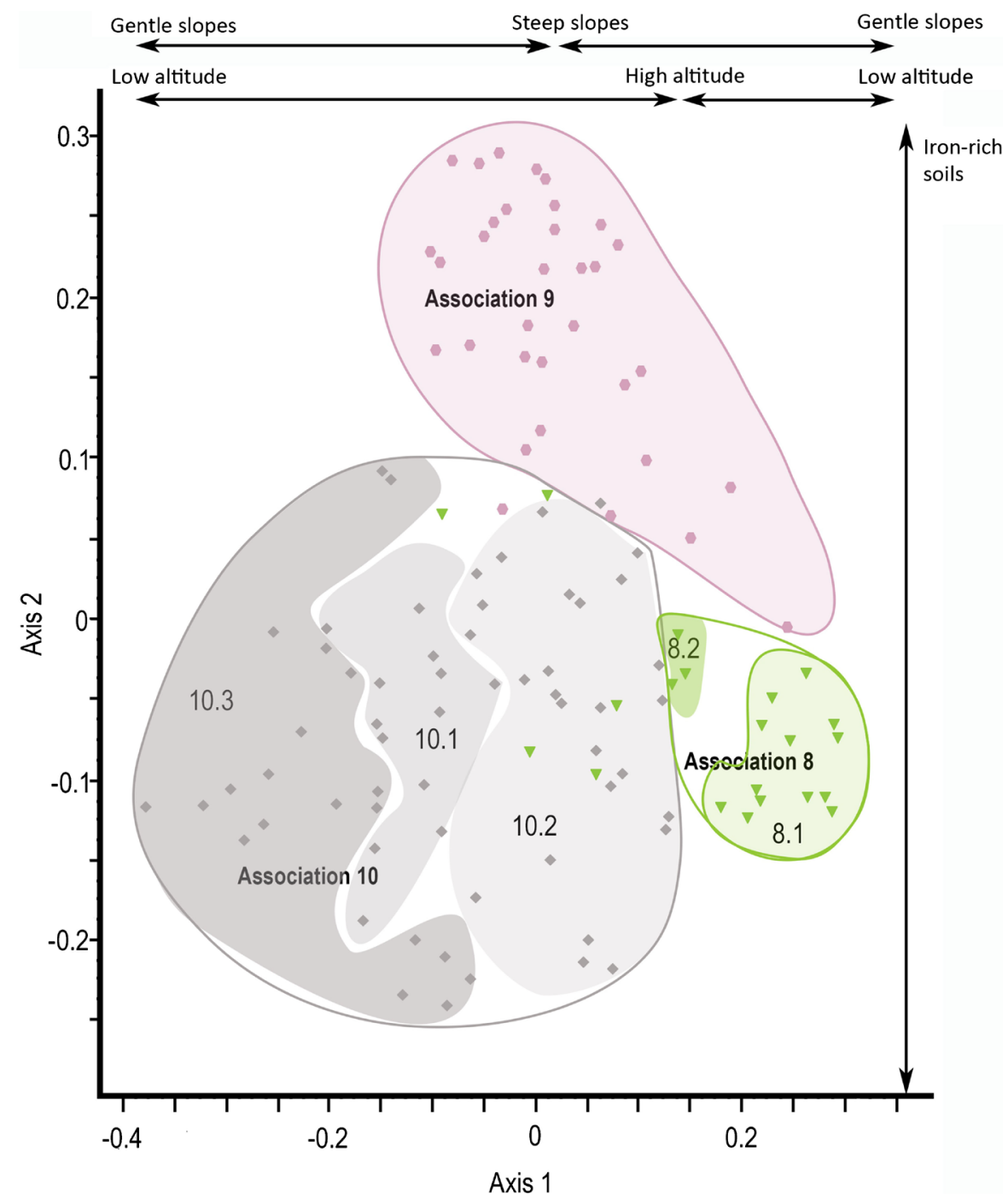

Figure 5. Principal Coordinate Analysis of the floristic data of the second cluster, associations $8-10$.

than $20 \%$ (Table 1) and 90 species had a frequency of occurrence greater than $10 \%$.

\subsection{Description of Plant Associations and Subassociations}

All plant taxa recorded in sample plots are listed in the synoptic table (Appendix A) and the location of the plant associations is indicated on the vegetation map (Figure 7).

\section{A1. Nephrolepis biserrata - Elaeis guineensis Anthropogenic Vegetation}

This association represented village garden vegetation. Plant species confined to this association were mostly edible or utilisable species such as Mangifera indica, Musa paradisiaca, Ananas comosus, Dacryodes edulis, Persea americana and Elaeis guineensis (species group A, Appendix A). Several indigenous tree species were also present such as Heisteria parvifolia, Sterculia tragacantha, Trichilia monadelpha and Coelocaryon preussii, while the fern Nephrolepis biserrata 


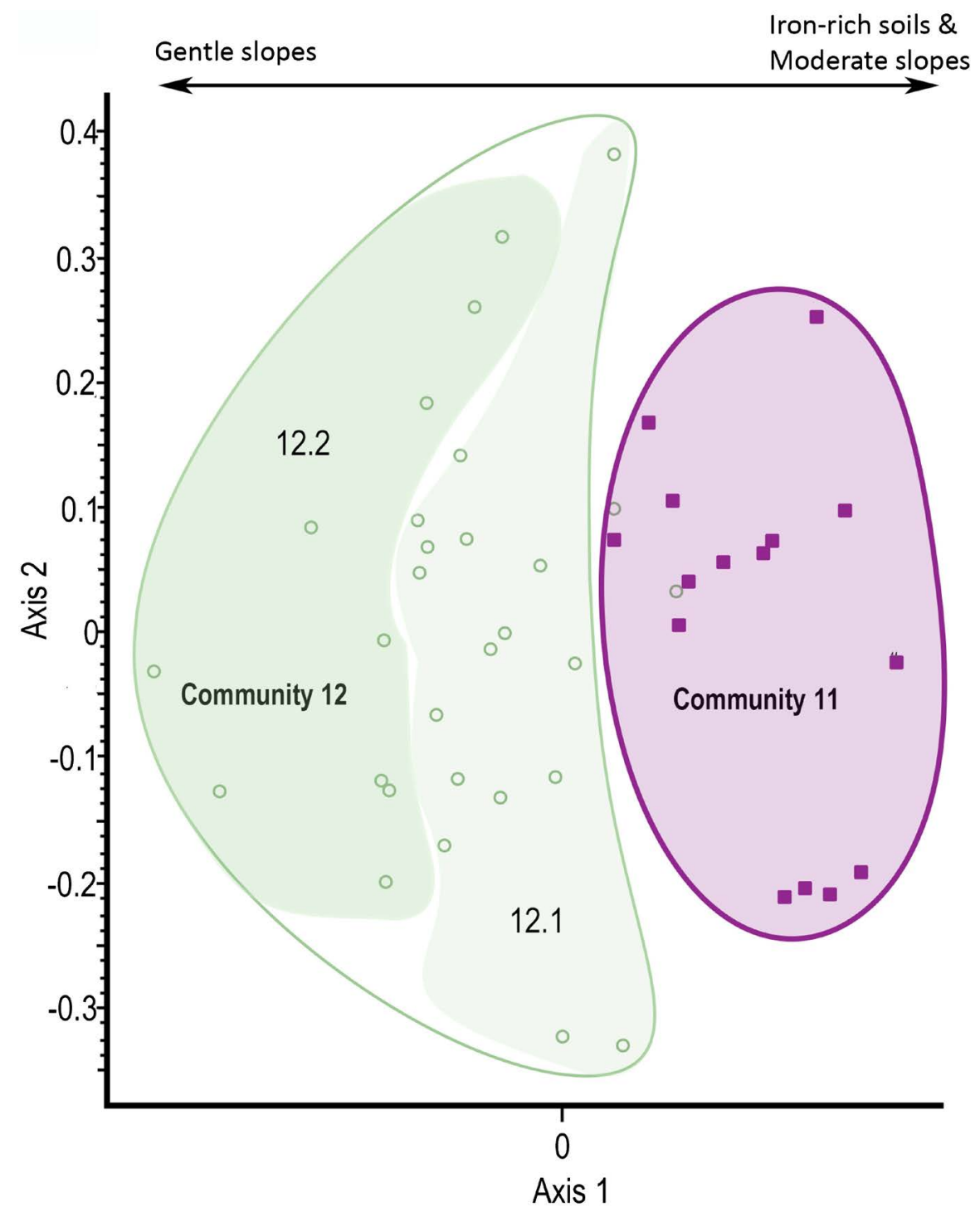

Figure 6. Principal Coordinate Analysis of the floristic data of the third cluster, associations 11 and 12.

was the most prominent species in the herbaceous layer.

A2. Anthocleista schweinfurthii - Musanga cecropioides Degraded Forest and Fern Glades

These highly degraded forests and fern glades occurred predominantly in a band from the southwest to northeast in the study area (Figure 7) and were associated with human activities such as agriculture and settlements. A1 and A2 together formed a highly transformed anthropogenic zone within the moist tropical forest and consisted of a combination of heavily degraded forests; secondary regrowth forests (Musanga cecropioides nurseries); fern glades; old and new cropland and gardens. A2 occurred predominantly on plains and occasionally on footslopes, at a mean altitude of $660 \mathrm{~m}$ above sea level (a.s.l.). The terrain was generally flat or gently sloping in a northwesterly or southwesterly direction. In places the soil could get waterlogged, however, it would rarely be swampy. 
Table 1. The plant species (from a total of 650 species sampled), with a frequency of occurrence greater than 20\%, observed in the Mayoko study area, Republic of Congo.

\begin{tabular}{|c|c|c|c|}
\hline Species & Frequency & Species & Frequency \\
\hline Plagiostyles africana & 66.8 & Agelaea paradoxa & 31.9 \\
\hline Coelocaryon preussii & 65.1 & Anisophyllea purpurascens & 31.1 \\
\hline Aucoumea klaineaena & 62.6 & Dacryodes pubescens & 30.6 \\
\hline Uapaca guineensis & 59.6 & Geophila afzelii & 29.4 \\
\hline Alchornea floribunda & 55.3 & Rourea obliquifoliolata & 28.9 \\
\hline Greenwayodendron suaveolens & 54.0 & Myrianthus preussii & 28.5 \\
\hline Santiria trimera & 49.4 & Carapa procera & 28.1 \\
\hline Trachyphrynium braunianum & 46.0 & Eremospatha macrocarpa & 27.2 \\
\hline Heisteria parvifolia & 46.0 & Celtis adolfi-friderichii & 27.2 \\
\hline Pycnanthus angolensis & 43.8 & Trichoscypha acuminata & 26.0 \\
\hline Pentaclethra macrophylla & 43.4 & Leptaspis zeylanica & 25.5 \\
\hline Petersianthus macrocarpus & 41.7 & Pentaclethra eetveldiana & 23.8 \\
\hline Agelaea pentagyna & 40.4 & Dichostemma glaucescens & 23.8 \\
\hline Piptadeniastrum africanum & 36.2 & Klainedoxa gabonensis & 23.4 \\
\hline Guaduella oblonga & 34.0 & Palisota ambigua & 22.1 \\
\hline Tabernaemontana crassa & 33.6 & Marantochloa conferta & 22.1 \\
\hline Strombosia grandiflora & 33.2 & Laccosperma secundiflorus & 21.7 \\
\hline Treculia obovoidea & 33.2 & Zanthoxylum heitzii & 21.3 \\
\hline Dialium pachyphyllum & 33.2 & Shirakiopsis elliptica & 20.9 \\
\hline Microdesmis camerunensis & 32.3 & Landolphia ligustrifolia & 20.9 \\
\hline Symphonia globulifera & 31.9 & Xylopia aethiopica & 20.0 \\
\hline
\end{tabular}

Clay content of the soil was intermediate.

The diagnostic species differentiating this association included Anthocleista schweinfurthii (tall tree), Vernonia conferta (shrub) and Pteridium aquilinum (fern) (species groups B \& C, Appendix A).

- Although medium to tall tree species ( $\geq 25 \mathrm{~m}$ ) were present, e.g. Pentaclethra macrophylla, Albizia zygia, Musanga cecropioides and Anthocleista schweinfurthii, the tree layer was not well developed. Small tree species $(<25 \mathrm{~m})$ were more numerous and included Harungana madagascariensis, Albizia adianthifolia and Hymenocardia ulmoides, all common pioneer species.

- The shrub layer was characterised by Vernonia conferta, Alchornea cordifolia, a medicinal plant, and the alien invasive species Lantana camara and Chromolaena odorata.

- The herbaceous layer was dominated by Pteridium aquilinum, while other common herbaceous species included Aframomum alboviolaceum, Ipomoea mauritiana and Costus afer. The grass layer was poorly developed because of 


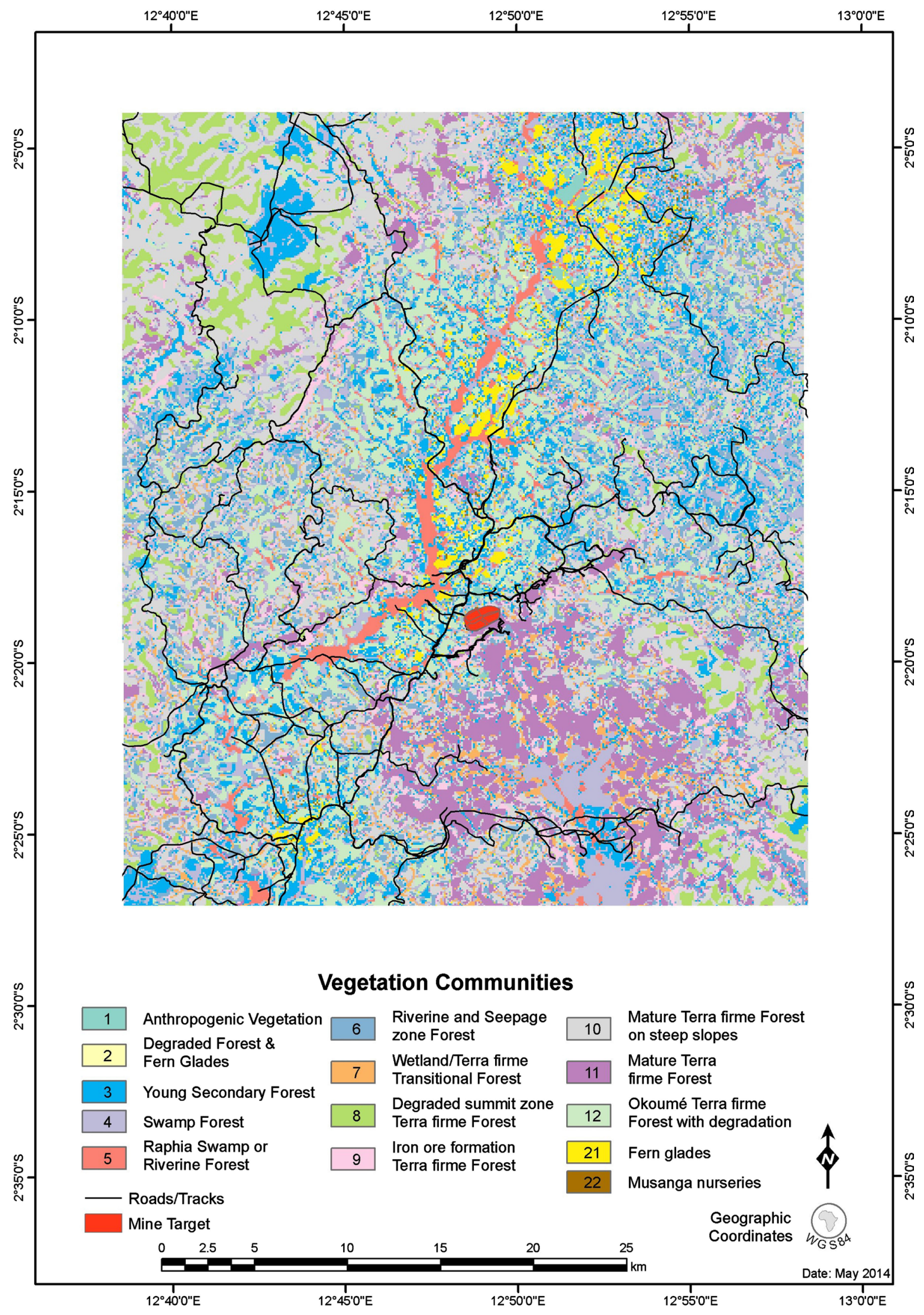

Figure 7. The vegetation map of the Mayoko study area, Republic of Congo. 
dense undergrowth and the most prominent grass species were Setaria megaphylla and Megastachya mucronata.

- The ratio of pioneer:young secondary:old secondary:primary species (referred to as successional ratio henceforth) on the basis of pollen data was 1.0:1.0:1.1:1.1, indicating a low proportion of old secondary and primary species in this degraded forest.

A3. Dinophora spenneroides - Selaginella myosurus - Scleria secans Young Secondary Forest

The association represented young secondary regrowth and often occurred along roads and tracks that cut through the forest, and on sites where the forest had been clear-cut. A strong human impact on vegetation was apparent.

Diagnostic species were Scleria secans (sedge), Clappertonia polyandra (shrub) and Setaria sphacelata (grass) (species group D, Appendix A).

- The dominant tree species were pioneers, such as Musanga cecropioides, Harungana madagascariensis, Macaranga spp. and Xylopia aethiopica. Aucoumea klaineana had high cover values in some instances, but overall, tree cover was fairly low.

- In the shrub layer Dinophora spenneroides was prominent. Other shrubs encountered included Oncoba glauca and Clappertonia polyandra.

- The herbaceous layer was well developed with a high cover of ferns, notably Selaginella myosurus and Lycopodiella cernua and the sedge Scleria secans. Grasses were represented by Setaria sphacelata, Panicum parvifolium and Guaduella oblonga.

A4. Anthocleista vogelii - Acroceras zizanoides Swamp Forest

A4 represented a true swamp forest, occurring where inundated conditions prevailed. The terrain was generally flat or with a slight slope in a northwesterly direction. Mean altitude was $684 \mathrm{~m}$ a.s.l. and clay content was intermediate.

Diagnostic species included Anthocleista vogelii (tall tree), Acroceras zizanoides (grass), Scleria racemosa (sedge) and Ludwigia abyssinica (herb) (Species group I, Appendix A).

- Tall trees ( $\geq 25 \mathrm{~m})$ were characterised by Alstonia boonei, Aucoumea klaineana and Symphonia globulifera. The dominant small tree species $(<25 \mathrm{~m})$ were Dichaetanthera strigosa, Harungana madagascariensis, Anthocleista vogelii and Xylopia aethiopica.

- In the shrub layer Dinophora spenneroides, Gardenia imperialis, Alchornea cordifolia, Alchornea floribunda and Chryptolepis oblongifolia were the most abundant species.

- The palms Raphia vinifera and Elaeis guineensis were common in parts of the association, with Eremospatha haullevilleana, Eremospatha wendlandiana and Laccosperma secundiflorum occasionally encountered.

- Ferns such as Selaginella myosurus, Lycopodiella cernua, Azolla pinnata, Christella dentata, Lygodium microphyllum, and Nephrolepis biserrata were prominent. 
- The grass layer was represented by Leersia hexandra, Panicum brevifolium, Acroceras zizanoides and Panicum parvifolium. Sedges were prominent and included Rhynchospora corymbosa, Cyperus pectinatus, Scleria boivinii, Scleria racemosa and Fuirena umbellata. Other herbaceous species were Aframomum citratum, Costus afer and Halopegia azurea as well as the aquatic plant species Ceratophyllum demersum, Nymphaea nouchali and Ludwigia adscendens.

- Based on pollen data the successional ratio was 1.0:1.1:1.0:1.3, indicating a fairly low proportion of primary species.

\section{A5. Berlinia bracteosa - Raphia vinifera Swamp or Riverine Forest}

This association occurred in low-lying areas (mean altitude $594 \mathrm{~m}$ a.s.l.), and was a mixture of riverine forests and swamp forests. It occurred across most of the study area where poor drainage conditions were found. Where rivers or streams had changed courses and left oxbows behind, pools often remained, resulting in localised pockets of swamp forests. The soil was usually waterlogged for most of the year. The terrain was generally flat, and a few stones and rocks occurred.

Diagnostic species were Berlinia bracteosa (tall tree) and Millettia griffoniana (small tree or shrub) (species group N, Appendix A).

- A large component of tall tree species ( $\geq 25 \mathrm{~m}$ ) was present, e.g. Gilbertiodendron dewevrei, Gilbertiodendron ogoouense, Berlinia bracteosa, Hallea stipulosa, Symphonia globulifera, Pseudospondias microcarpa, Coelocaryon preussii and Uapaca guineensis. Small tree species $(<25 \mathrm{~m})$, such as Sterculia tragacantha, Homalium africanum, Macaranga schweinfurthii, Xylopia rubescens and Carapa procera were also abundant.

- Shrubs and woody climbers were represented by Millettia griffoniana, Argocoffeopsis eketensis, Leea guineensis, Alchornea floribunda and Combretum racemosum.

- Palms such as Raphia vinifera, Eremospatha wendlandiana and Laccosperma laeve were prominent.

- Few grass and sedge species were recorded, the most prominent being Leptaspis zeylanica and Mapania heteromorpha. Other herbaceous species were Acanthus sp. and Halopegia azurea. Ferns were mainly represented by Christella dentata and Microsorum punctatum.

- A successional ratio of 1.0:1.2:1.3:2.2 was obtained. This was the highest ratio of primary:pioneer species amongst the wetland associations.

A6. Sterculia tragacantha - Agelaea paradoxa Riverine and Temporary Inundated Forest

A6 was spread across most of the study area and was associated with small river courses, and temporarily inundated sites/seepage zones on foot slopes. Mean altitude was $628 \mathrm{~m}$ a.s.l. Terrain was flat or gently sloping, mostly in a northeasterly direction. Clay content of the poorly drained soils was low to intermediate. 
A6 was not differentiated by a diagnostic species group. It shared many species with other swamp and riverine forest associations but also with the terra firme forest associations.

- Tall trees $(\geq 25 \mathrm{~m})$ were characterised by Greenwayodendron suaveolens, Hallea stipulosa, Aucoumea klaineana, Pentaclethra macrophylla, Pycnanthus angolensis, Symphonia globulifera and Uapaca guineensis, whereas dominant small tree species $(<25 \mathrm{~m})$ were Sterculia tragacantha and Tabernaemontana crassa.

- Common species in the shrub layer were Alchornea floribunda and the lianas Agelaea paradoxa, Agelaea pentagyna and Rourea obliquifoliolata.

- Many palm species were recorded, the most prominent being Eremospatha macrocarpa, Eremospatha wendlandiana, Laccosperma laeve and Laccosperma secundiflorum.

- Guaduella oblonga and Leptaspis zeylanica were the most abundant grass species. Other common herbaceous species included Begonia elatostemma, Begonia ampla, Marantochloa congensis, Marantochloa conferta, Trachyphrynium braunianum, Palisota ambigua, Geophila afzelii and ferns such as Cyathea manniana, Selaginella myosurus and Nephrolepis bisserata.

- The successional ratio was 1.0:1.1:1.2:1.8, indicating the second highest ratio of primary species amongst the wetland associations.

\section{A7. Lonchitis currori - Ctenitis protensa Wetland/Terra firme Transi-} tional Forest

A7 was found predominantly on the eastern part of the iron ore containing formation. Terrain was predominantly flat, but where slopes occurred they were mostly in a northwesterly or northeasterly direction. The soil was generally well drained, except for the swampy sites in SA7.1 and clay content was low. Clear signs of logging were noted at most sampled sites.

The diagnostic species included Lonchitis currori (fern), Ctenitis protensa (fern), Agelaea poggeana (liana), Eremospatha korthalsiifolia (palm), Podococcus acaulis (palm) and Corynanthe mayumbensis (tree) (species group W, Appendix A).

- Tall trees ( $\geq 25 \mathrm{~m}$ ) were characterised by Greenwayodendron suaveolens, Dacryodes pubescens, Dialium pachyphyllum, Hylodendron gabunense, Piptadeniastrum africanum and Uapaca guineensis, whereas the dominant small tree species $(<25 \mathrm{~m})$ were Corynanthe mayumbensis, Aphanocalyx microphyllus, Tabernaemontana crassa, Trichoscypha acuminata, Plagiostyles africana, Santiria trimera and Treculia obovoidea.

- Shrubs such as Scaphopetalum blackii, Alchornea floribunda, Olax gambecola, Alchornea hirtella, Microdesmis camerunensis, and scandent shrubs Manniophyton fulvum, Manotes expansa and Ancistrocarpus densispinosus were abundant.

- Palms were a prominent feature and the most conspicuous species included Podococcus acaulis, Eremospatha korthalsiifolia, Eremospatha wendlandiana and Laccosperma secundiflorum. 
- Common grass species were Guaduella oblonga and Leptaspis zeylanica and the most conspicuous sedge species were Hypolytrum heteromorphum and Mapania mannii. The most abundant forbs were Begonia microsperma, Palisota schweinfurthii, Trachyphrynium braunianum, Geophila afzelii, Agelaea pentagyna, Afrocalathea rhizantha, Impatiens irvingii, Costus afer and Halopegia azurea.

- A well-developed fern layer, comprising mainly Lonchitis currorii, Ctenitis protensa, Cyathea camerooniana and Marattia fraxinea, was present.

- A successional ratio of 1.0:1.1:1.1:1.4 was obtained.

A8. Syzygium staudtii - Pseudospondias longifolia degraded Terra firme Forest

A8 had a disjunct distribution with subassociation SA8.1 predominantly occupying an area in the northwest and SA8.2 occupying the southern part of the study area (Figure 7). There was a distinct difference in altitude between SA8.1 (769 $\mathrm{m}$ a.s.l.) and SA8.2 (666 $\mathrm{m}$ a.s.l.). The association generally occupied middle to upper slopes and rounded summits of the undulating and gently sloping terrain. Most slopes faced a northwesterly direction. Clay content of the moderately to well-drained soil was intermediate.

The diagnostic species included Syzygium staudtii, Pseudospondias longifolia, Scorodophloeus zenkeri, Funtumia africana and Aporrhiza sp. (species group $\mathrm{AB}$, Appendix A).

- Tall tree species $(\geq 25 \mathrm{~m})$ were characterised by species such as Syzygium staudtii., Aucoumea klaineana, Distemonanthus benthamianus, Pentaclethra macrophylla and Uapaca guineensis and the dominant small tree species ( $<25 \mathrm{~m})$ were Hymenocardia ulmoides, Maesobotrya sp., Strombosia grandifolia, Tabernaemontana crassa, Shirakiopsis elliptica, Dichostemma glaucescens, Heisteria parvifolia, Plagiostyles africana and Santiria trimera.

- The most prominent shrubs were Alchornea floribunda, Microdesmis camerunensis, and scandent shrubs Dalhousiea africana and Rourea obliquifoliolata.

- Several palm species were recorded, amongst others Raphia regalis, Eremospatha macrocarpa, Eremospatha wendlandiana, Sclerosperma mannii and Laccosperma secundiflorum.

- Only a few grass species were recorded, the most prominent being Leptaspis zeylanica and Guaduella oblonga. Other herbaceous species were Agelaea pentagyna, Sarcophrynium schweinfurthianum Trachyphrynium braunianum, Marantochloa conferta, and Palisota ambigua.

- The successional ratio was 1.0:1.1:1.5:2.5, the highest ratio of primary to pioneer species among the terra firme associations.

A9. Scaphopetalum zenkeri - Guaduella oblonga Terra firme Forest on the iron formation

This forest association occurred primarily on the iron-ore-rich hills in the centre of the study area. It occurred predominantly on moderately steep midslopes facing a southerly direction. Clay content of the moderately drained soils 
was intermediate. Mean altitude was $700 \mathrm{~m}$ a.s.l.

The association was differentiated, amongst others, by Scaphopetalum zenkeri (shrub), Oxyanthus speciosus (shrub/small tree), Tiliacora funifera (liana) and Antrocaryon micraster (tall tree) (species group AG, Appendix A).

- The dominant tall tree species ( $\geq 25 \mathrm{~m}$ ) were Greenwayodendron suaveolens, Coelocaryon preussii, Aucoumea klaineana, Pentaclethra macrophylla, Strombosia grandiflora, Symphonia globulifera and Uapaca guineensis, whereas the dominant small tree species $(<25 \mathrm{~m})$ were Santiria trimera, Heisteria parvifolia, Treculia obovoidea and Plagiostyles africana.

- The shrub layer was characterised by Alchornea floribunda and the liana Agelaea paradoxa, Agelaea pentagyna, Tiliacora funifera, Landolphia ligustrifolia and Rourea obliquifoliolata.

- Palm species included Raphia regalis, Eremospatha macrocarpa, Eremospatha wendlandiana, Podococcus barteri and Laccosperma secundiflorum.

- The most prominent grass species were Guaduella oblonga and Leptaspis zeylanica. Other common herbaceous species included Marantochloa conferta, Trachyphrynium braunianum, Palisota ambigua, Palisota hirsuta, Palisota satabiei, Geophila afzelii. Ferns were notably absent.

- The successional ratio was 1.0:1.1:1.3:2.2.

A10. Greenwayodendron suaveolens - Alchornea floribunda Mature Terra firme Forest on steep slopes

This association was found mainly in the southeast of the study area. Topography ranged from valleys to upper slopes at a mean altitude of $697 \mathrm{~m}$ a.s.l. Slopes were predominantly in a northeasterly direction and inclines ranged from gentle to steep. Clay content of the moderately to well-drained soils was intermediate.

The weak diagnostic species group (species group AK, Appendix A) contained species such as Xylopia staudtii, Strombosiopsis tetrandra, Quassia africana and Garcinia smeathmanii.

- The dominant tall tree species ( $\geq 25 \mathrm{~m}$ ) were Greenwayodendron suaveolens, Coelocaryon preussii, Aucoumea klaineana, Strombosia grandiflora, Dialium pachyphyllum, Petersianthus macrocarpus and Uapaca guineensis, whereas dominant small tree species $(<25 \mathrm{~m})$ were Santiria trimera, Heisteria parvifolia, Treculia obovoidea and Plagiostyles africana.

- The shrub layer was characterised by Alchornea floribunda and the liana Agelaea paradoxa, Agelaea pentagyna, Landolphia ligustrifolia and Rourea obliquifoliolata.

- Palms were represented by Raphia regalis, Eremospatha macrocarpa, Eremospatha wendlandiana, Podococcus barteri, Laccosperma laeve and Laccosperma secundiflorum.

- The most prominent grass species were Guaduella oblonga and Leptaspis zeylanica. Other common herbaceous species included Marantochloa con- 
ferta, Trachyphrynium braunianum, Palisota ambigua, Palisota satabiei and Geophila afzelii. Ferns were notably absent.

- The successional ratio was 1.0:1.2:1.4:2.3.

A11. Guarea cedrata - Celtis adolfi-friderici - Santiria trimera Mature Terra firme Forest

A11 was found predominantly on the iron-ore-bearing hills with some patches in the northeast. Mean altitude was $663 \mathrm{~m}$ a.s.l. The association occurred on foot to upper slopes with inclines ranging from gentle through moderate to steep. Slope direction of the survey plots was almost equally divided between a northwesterly, northeasterly and southwesterly direction. Soils had an intermediate clay content and were moderately to well-drained. Tree logging was recorded at almost all sites surveyed.

This association was differentiated by the poorly-defined, single species, Engomegoma gordonii., diagnostic species group AV and the absence of most species from species groups A to AU was prominent (species group AV, Appendix A).

- Tall tree species ( $\geq 25 \mathrm{~m}$ ) were characterised by Dacryodes pubescens, Guarea cedrata, Strombosia pustulata, Pentaclethra macrophylla, Coelocaryon preussii, Pycnanthus angolensis and Aucoumea klaineana. The most notable small tree species $(<25 \mathrm{~m})$ were Celtis adolfi-friderici, Heisteria parvifolia, Plagiostyles africana and Santiria trimera.

- No floristic survey of the shrub or herbaceous layer was undertaken in the plots representing this association.

- The successional ratio was not calculated because only tree species were recorded in this association.

A12. Aucoumea klaineana - Uapaca guineensis Terra firme Forest with degradation

A12 occurred predominantly in the north of the study area. Because it was located in fairly close proximity to villages and towns it had a relatively high level of disturbance with tree logging recorded at almost all sites surveyed. The association was mostly found on gently undulating terrain, but could on occasion occupy any position from plains to upper slopes. The slope direction varied but generally faced a westerly direction. Clay content of the moderately to well-drained soils was intermediate. The mean altitude was $658 \mathrm{~m}$ a.s.l.

This association was not differentiated by a diagnostic species group but absence of most species from species groups A to AW was notable.

- The most prominent tall tree species ( $\geq 25 \mathrm{~m}$ ) were Pentaclethra macrophylla, Petersianthus macrocarpus, Coelocaryon preussii, Piptadeniastrum africanum, Pycnanthus angolensis, Dialium pachyphyllum, Uapaca guineensis and Aucoumea klaineana. The dominant small tree species $(<25 \mathrm{~m})$ were Celtis adolfi-friderici, Albizia ferruginea, Greenwayodendron suaveolens, Plagiostyles africana and Santiria trimera.

- No floristic survey of the shrub or herbaceous layer was undertaken in the plots representing this association. 
- The successional ratio was not calculated because only tree species were recorded in this association.

\subsection{Association Structure}

The associations with a high level of anthropogenic influence (A1 - A3) had no or a very poorly developed tree stratum (Table 2 ). The herbaceous layer was best

Table 2. Summary of mean height and mean cover of tree, shrub and herbaceous strata in the different associations at the Mayoko study site, Republic of Congo.

\begin{tabular}{|c|c|c|c|c|c|c|c|c|c|c|}
\hline \multirow{2}{*}{ Stratum } & \multicolumn{10}{|c|}{ Mean height (m) } \\
\hline & $\mathrm{A} 2$ & $\mathrm{~A} 4$ & A5 & A6 & A7 & A8 & A9 & $\mathrm{A} 10$ & A11 & $\mathrm{A} 12$ \\
\hline \multicolumn{11}{|l|}{ Tree layer } \\
\hline Emergent canopy & Absent & 34 & 34 & 39 & 43 & 42 & 36 & 37 & 47 & 43 \\
\hline Upper canopy & 20 & 23 & 28 & 32 & 32 & 30 & 30 & 29 & 39 & 35 \\
\hline Mid-canopy & Absent & 18 & 19 & 21 & 21 & 20 & 15 & 20 & 28 & 24 \\
\hline Lower canopy & 1.0 & 1.0 & 0.8 & 0.7 & 1.5 & 1.3 & 0.5 & 0.6 & 1.6 & 1.6 \\
\hline \multicolumn{11}{|l|}{ Shrub layer } \\
\hline Very high canopy & 15 & 10 & 9 & 10 & 14 & 15 & 15 & 10 & 18 & 18 \\
\hline Upper canopy & 9 & 8 & 6 & 7 & 10 & 11 & 9 & 6 & 14 & 14 \\
\hline Mid-canopy & 5 & 4 & 4 & 3 & 5 & 7 & 5 & 2 & 9 & 9 \\
\hline Lower canopy & 1.8 & 1.2 & 1.0 & 1.1 & 2.0 & 1.9 & 1.4 & 0.7 & 2.0 & 2.0 \\
\hline \multicolumn{11}{|l|}{ Herbaceous layer } \\
\hline Very high canopy & Absent & 4 & 11 & 8 & Absent & 6 & 9 & 10 & Absent & Absent \\
\hline Upper canopy & Absent & 2 & 5 & 4 & 4 & 11 & 4 & 4 & 13 & 13 \\
\hline Mid-canopy & 2 & 1 & 2 & 1 & 2 & 4 & 2 & 1 & 6 & 5 \\
\hline Lower canopy & 1.6 & 0.7 & 0.7 & 0.7 & 0.6 & 1.3 & 0.5 & 0.6 & 1.5 & 1.4 \\
\hline & \multicolumn{10}{|c|}{ Mean cover (\%) } \\
\hline \multicolumn{11}{|l|}{ Tree layer } \\
\hline Emergent canopy & 0 & 9 & 33 & 40 & 3.0 & 33 & 37 & 52 & 38 & 36 \\
\hline Upper canopy & 2 & 28 & 59 & 64 & 2.0 & 57 & 83 & 57 & 63 & 63 \\
\hline Mid-canopy & 0 & 25 & 31 & 41 & 2.1 & 33 & 58 & 38 & 47 & 40 \\
\hline Lower canopy & 3 & 19 & 35 & 27 & 0.0 & 13 & 29 & 17 & 37 & 37 \\
\hline \multicolumn{11}{|l|}{ Shrub layer } \\
\hline Very high canopy & 14 & 17 & 31 & 27 & 0.7 & 10 & 51 & 34 & 7 & 3 \\
\hline Upper canopy & 18 & 20 & 22 & 27 & 0.8 & 22 & 47 & 28 & 37 & 33 \\
\hline Mid-canopy & 4 & 23 & 25 & 25 & 0.6 & 26 & 51 & 26 & 37 & 32 \\
\hline Lower canopy & 16 & 20 & 37 & 39 & 0.0 & 29 & 50 & 35 & 51 & 57 \\
\hline \multicolumn{11}{|l|}{ Herbaceous layer } \\
\hline Very high canopy & 0 & 22 & 32 & 16 & - & 1.5 & 2 & 23 & 0 & 0 \\
\hline Upper canopy & 0 & 23 & 23 & 17 & 0.6 & 3 & 5 & 22 & 4 & 5 \\
\hline Mid-canopy & 19 & 48 & 40 & 29 & 0.4 & 4 & 22 & 30 & 12 & 10 \\
\hline Lower canopy & 37 & 55 & 47 & 44 & 0.1 & 11 & 54 & 36 & 47 & 42 \\
\hline
\end{tabular}


developed and could cover up to $95 \%$ of the area. Among the wetland associations there was a progression from A4 - A7 in development of the tree stratum. Shrub and herbaceous strata were variably developed, depending on the habitat conditions. Among the terra firme associations (A9 - A12) all associations had a well-developed tree layer. The tree layer was best developed in A10 and A11, with A10 having the highest canopy cover for the emergent layer (52\%) and A11 having the highest mean height for emergent and upper canopy layers of all associations ( $47 \mathrm{~m}$ and $39 \mathrm{~m}$ respectively).

\subsection{Diversity}

A7 and A9 had the highest mean plot values for species richness, Shannon-Wiener $\left(H^{\prime}\right)$, exponent $H^{\prime}$ and Simpson index (Table 3). Among the wetland associations, A4, A5 and A6 had intermediate values for both species richness per plot as well as Shannon-Wiener index of diversity and among the terra firme associations $\mathrm{A} 8$ and $\mathrm{A} 10$ had intermediate values. The lowest per plot values for most of the diversity parameters were generally found in A2 and A12. For the associations as a whole, the highest number of species, highest $\mathrm{H}^{\prime}$ and highest exponent $\mathrm{H}^{\prime}$ were found in A7, A9 and A10.

\section{Discussion}

\subsection{Phytogeography and Endemism}

The Congo Basin contains the world's second largest dense, humid, tropical forests,

Table 3. Summary of species richness, evenness, Shannon-Wiener, exponent of Shannon-Wiener and Simpson index of diversity for the different plant associations at the Mayoko study site, Republic of Congo.

\begin{tabular}{|c|c|c|c|c|c|c|c|c|c|c|c|}
\hline \multirow{2}{*}{$\begin{array}{c}\text { Association } \\
\text { no }\end{array}$} & \multirow{2}{*}{$\begin{array}{l}\text { No of } \\
\text { plots }\end{array}$} & \multirow{2}{*}{$\begin{array}{l}\text { Total no } \\
\text { of species }\end{array}$} & \multicolumn{5}{|c|}{ Mean per plot } & \multicolumn{4}{|c|}{ Association as a whole } \\
\hline & & & Richness & Evenness & Shannon & Exp Shannon & Simpson & Alpha & Shannon & Exp Shannon & $\begin{array}{c}\text { Simpson } \\
\text { Inverse }\end{array}$ \\
\hline 1 & 1 & 35 & 35 & 0.67 & 2.38 & 10.80 & 0.85 & 12.05 & 2.34 & 10.40 & 5.99 \\
\hline 2 & 7 & 54 & 14 & 0.55 & 1.45 & 4.26 & 0.54 & 11.07 & 2.98 & 19.60 & 8.34 \\
\hline 4 & 12 & 180 & 33 & 0.83 & 2.76 & 15.80 & 0.90 & 33.85 & 4.42 & 82.95 & 55.84 \\
\hline 5 & 18 & 175 & 27 & 0.73 & 2.33 & 10.28 & 0.81 & 36.49 & 4.21 & 67.66 & 40.64 \\
\hline 6 & 20 & 240 & 39 & 0.78 & 2.84 & 17.12 & 0.90 & 52.98 & 4.39 & 80.30 & 41.84 \\
\hline 7 & 13 & 295 & 60 & 0.84 & 3.41 & 30.27 & 0.94 & 58.08 & 4.84 & 126.06 & 76.24 \\
\hline 9 & 35 & 274 & 53 & 0.87 & 3.42 & 30.57 & 0.95 & 55.23 & 4.68 & 107.28 & 58.10 \\
\hline 10 & 57 & 272 & 39 & 0.79 & 2.87 & 17.64 & 0.90 & 50.44 & 4.47 & 87.11 & 48.32 \\
\hline 11 & 16 & 64 & 14 & 0.77 & 2.04 & 7.69 & 0.79 & 12.43 & 3.41 & 30.40 & 20.82 \\
\hline 12 & 28 & 67 & 11 & 0.67 & 1.55 & 4.71 & 0.67 & 11.82 & 2.52 & 12.45 & 5.84 \\
\hline All & & & & & & & & & 5.20 & 181.00 & 91.90 \\
\hline
\end{tabular}

Note: plant associations 1, 2, 3, 4 and 7 have low sampling levels and must be considered as inadequate representations of the associations they illustrate. 
surpassed only by the Amazonian Basin. Phytochorologically, the region belongs to the Guineo-Congolian regional centre of endemism (White, 1979, 1983; Linder et al., 2005). Three subcentres of endemism are recognised within the region, with the Mayoko study area considered part of the Congolia subcentre of endemism.

\subsection{Forest Structure and Physiognomy}

White (1983) distinguished three main structural vegetation types in the Congo Basin: the Wet Guineo-Congolian Tropical Rainforest; the Dry Guineo-Congolian Tropical Rainforest and the Rainforest-Secondary Grassland Mosaic. The Mayoko study site is located within the wet Guineo-Congolian Tropical Rainforest. These forests include: a) the coastal evergreen rainforest characterised by Aucoumea klaineana and Sacoglottis gabonensis in the Congo and referred to as "Atlantic littoral forest" by Letouzey (1968, 1985); and b) the mixed moist semi-evergreen rainforest or "Congolian forest" (Letouzey, 1968, 1985). The wet Guineo-Congolian tropical rainforest represents the climax ecosystem in the region. The high canopy cover of the woody layer precludes the development of a herbaceous stratum and favours epiphytes (Lebamba et al., 2009). In the current study area, both evergreen and mixed moist semi-evergreen rainforest types occurred.

Vande Weghe (2004) used a different physiognomic-topographic system and recognized six main groups of terra firme forests in central Africa. The Lowland evergreen forest and Lowland semi-deciduous forests are applicable to the Mayoko study area. The Lowland evergreen forests represent dense, humid, tropical forests with a variety of buttressed trees, lianas, epiphytes and a high forest canopy. The Lowland semi-deciduous forests often form a zone around the core evergreen forests. These forests are rich in species belonging to the Meliaceae. Lianas and epiphytes are less abundant than in the evergreen forests, often being entirely absent.

According to the land cover map of Africa depicting 27 land cover classes (Mayaux, 2004), the study area is classified as Closed Evergreen Lowland Forest, occurring below $900 \mathrm{~m}$ altitude with a tree cover $>70 \%$ and an evergreen phenology.

\subsection{Species Accumulation Curves and Species Frequencies}

The species accumulation curve for all surveyed sites reached an asymptote and it can therefore be assumed that the field effort undertaken for the purpose of identifying common plant species across the entire study area was adequate. The point where a line representing one new sample adding one new species was tangent to the curve indicated adequate sampling for clusters 2 and 3 and marginal sufficiency for cluster 1 . The Michaelis-Menten richness estimator indicated that $>90 \%$ of the potential number of species was retrieved by the current sampling level for all plots combined as well as for cluster 2. For cluster 1 and 3 , 
$89 \%$ and $85 \%$ of the potential number of species had been retrieved.

An analysis of the frequency of occurrence of plant species in the study area showed a low mean frequency and even lower median and mode. Only six species ( $1 \%$ of all species) occurred in more than $50 \%$ of plots visited, and 42 species (6\% of all species) have frequencies of occurrence $>20 \%$ (Table 1 ). This pattern of occurrence is typical in tropical forests, which are characterised by both low frequency and low density of occurrence (Maguran \& McGill, 2011).

\subsection{Classification into Plant Associations}

Although tropical forest plant assemblages have been described as notoriously difficult to classify (Vande Weghe, 2004), distinct plant associations could be identified. The twelve associations were grouped into three clusters. Cluster 1 contained primarily severely degraded and moist associations (swamp, riverine and inundatable forest), whereas clusters 2 and 3 contained terra firme associations.

A1, A2 and A3 represented vegetation highly transformed by human activities. A strong floristic link existed between these anthropogenically transformed associations and swamp and riverine forests. A1 contained many introduced species planted in home gardens for household use. The fern glades of A2 were frequently observed around villages. Within these fern glades the forest is prevented from growing back through regular cutting of regrowth, thus favouring ferns above usual vigorous secondary tree species. Once firmly established, these ferns prevent secondary forest from developing. The Musanga cecropioides nurseries of A2 appear after forest slash-and-burn practices when natural forest regrowth is not actively prevented. This pioneer successional stage after the abandoning of cropland is a by-product of near constant human activity such as natural resource gathering (firewood, building material, food gathering, water gathering). Forest recovery rates after shifting agriculture is generally considered rapid if fields are small and embedded in a forest matrix; time of cultivation was only 1 - 2 years; the intensity of cultivation was low, no fires occurred and soil fertility is high (Chazdon, 2003; Kassi et al., 2008). Generally, A3 represented the forest formation that followed roads and clear-cut forests. It was an early successional stage containing many pioneer species. The anthropogenic influence was evident through the modified species composition and canopy structure.

A4 was a true swamp forest, which was particularly well developed in the study area's south on flood plains of larger rivers. A5 was a wetland association with a mixture of swamp, riverine and inundatable forest vegetation. SA5.1 occurred primarily along the large rivers, such as the Louessé River, and represented the best example of Gilbertiodendron dewevrei and Gilbertiodendron ogoouense forest in the study area. These large rivers serve as access ways through the forest and human interference is conspicuous. SA5.2 was associated with small rivers where stagnant pools develop and it was spread across most of the northern study area. SA6.1 represented either a riverine forest or inundatable 
forest where waterlogged conditions are not found year-round.

A7 was transitional between wetland and terra firme associations, containing floristic elements of both forests kinds. Widespread logging and fuelwood collection occurred in A7 and evidence could be seen by pioneer species abundance such as Musanga cecropioides, Anthocleista vogelii and Sarcophyrium schweinfurthii, in several plots.

Clusters 2 and 3 contained only terra firme forest associations. There was a distinct separation between these two clusters that could probably be ascribed to the fact that only woody species were recorded in associations comprising cluster 3.

Overall, A8 represented forests that had been logged over at different times in the past, with a difference in time since logging of approximately 20 years between the associations. SA8.1 was a degraded forest with some savanna elements and was restricted to high-lying areas in the northwest of the study area. Environmentally this forest may be related to near permanent cloud cover during the dry season at these altitudes. Both A9 and A10 occurred on mountain slopes, but A9 occurred specifically on hills where iron-ore-rich deposits occur, whereas A10 occurred to the south of the study area in the Mandodo region.

Because the shrub and herbaceous layers were not sampled in A11 and A12 inferences on these associations should be regarded as preliminary. A11 was found predominantly on the iron-rich mountains and it could perhaps be another subassociation of A9. A12 occurred at fairly low altitudes and was more typical of the northern section of the study area. Furthermore, A12 seemed to be a secondary forest with a high level of logging occurring. High levels of human-induced disturbance may be maintained in this association as it lies within a region that is relatively accessible through roads and the Louessé River. Alternatively, it could be a regenerating forest growing on areas left fallow subsequent to abandonment of various crops (coffee, rice, oil palm or cocoa) that were common in the region following independence and until the mid-1980s.

\subsection{Plant Diversity and Species Richness in the Mayoko Study Area}

The H' index for individual associations ranged from a low of 2.34 to 4.84, with the total for the entire study area being 5.2. By comparison, $H^{\prime}$ values of 3.34 to 4.14 have been reported for forests with gregarious species (Lope forest, Gabon; Senterre \& Lejoly, 2001) and from 5.24 to 5.46 in mixed forests (Dja forest, Cameroon; Senterre et al., 2004) to 5.79 in rainforest (Nsork, Equatorial Guinea, Senterre \& Lejoly, 2001). In Campo-Ma'an, Cameroon, H' index values ranged from 0.12 for mangroves to 5.33 for entire communities with the total for the entire Campo-Ma'an being 5.54. Mean values for 1 ha plots in Central Africa range from 3.72 to 4.00 (Gonmadje et al., 2011). Overall, the values reported within the current study area are within the range reported for other tropical forests in Central Africa. Compared to a similar study conducted in the forest communities in the Kouilou Département $\left(H^{\prime}=4.90\right)$ (Van Rooyen et al., 2017) 
the Mayoko region diversity is higher.

The highest species richness as well as $\mathrm{H}^{\prime}$ values per plot were reported for A7 and A9. The high plant diversity of A7 could be partly ascribed to it being transitional between wetland and terra firme associations and therefore containing species from both kinds of habitat. The iron-ore-rich hills targeted for mining also had a high plant diversity as indicated for A9. The lowest values for both species richness per plot and $\mathrm{H}^{\prime}$ were recorded for A2, A3, A11 and A12. The low value for A2 is probably due to the high level of disturbance in this association, whereas the low diversity of A11 and A12 is due to the fact that only the woody species were recorded.

\subsection{Dynamics of the Vegetation in the Mayoko Study Area}

An overview of the temporal changes occurring in central African tropical forests has been described by Vande Weghe (2004). Some general trends that can clearly be observed in the Mayoko study area are:

- Gaps created in the forest by tree-fall are generally quickly filled by a succession of species. One of the first species to colonize gaps is the fast-growing Musanga cecropioides. Other species, such as Anthocleista spp. also colonize gaps and are replaced after a few decades by other forest species. Natural tree-fall gaps rejuvenate the forest and maintain diversity by creating an assortment of species with different ages and different growth forms.

- Secondary succession is initiated when extensive areas of forest are destroyed by clear-cutting for roads, fire, agricultural deforestation or violent storms. Regeneration is fairly rapid if seeds, organic material and nutrients are present. The pioneer stage generally consists of shrubs, such as Vernonia conferta, Musanga cecropioides and Harungana madagascariensis (A2 and A3). After some years, regeneration of Caloncoba welwitschii, Anthocleista schweinfurthii, Oncoba glauca, Macaranga spp., Maesopsis eminii and Myrianthus arboreus occurs. These trees often constitute homogenous formations 15 - $20 \mathrm{~m}$ tall. Musanga cecropiodes remains dominant for some 20 years. Epiphytes are rare or absent.

- The herb and shrub layers in early successional stages are dense and composed of species of the Zingiberaceae, e.g. Costus and Afromomum, as well as Marantaceae, usually of the genera Haumania and Marantochloa and Palisota (Commelinaceae). Shrubs and small trees of the first stages in secondary succession, over a carpet of Pteridium aquilinum and Aframomum alboviolaceum (A2), are mainly Alchornea cordifolia (A2 \& A3), Caloncoba welwitschii (A7), Hymenocardia ulmoides (SA8.1) and Macaranga spinosa (A3, A6, A9 \& A10). Other taller trees whose saplings are quickly established include Anthocleista schweinfurthii (A2), Dichostemma glaucescens (most associations), Maprounea membranacea (A4 \& A6), Pentaclethra macrophylla (all associations), Pterocarpus soyauxii (most associations) and Xylopia aethiopica (most associations). These trees form a tall secondary forest together with Carapa procera (most associations), Odyendyea gabonensis 
(A7) and Croton mayumbensis, the latter reaching up to $40 \mathrm{~m}$ in places.

- The oldest secondary forests in the lowland evergreen forest zone are characterized by an abundance of Funtumia africana, Pentaclethra macrophylla, Ceiba pentandra, Pycnanthus angolensis and Zanthoxylum spp.

- The Marantaceae forests represent an intermediate stage between the pioneer and the mature forest. Openings that appear in the closed pioneer forest are usually invaded by many species belonging to the Zingiberaceae and Marantaceae that quickly form dense, impenetrable thickets. Notable tree species in these forests include Piptadeniastrum africanum, Pentaclethra eetveldiana, Canarium schweinfurthii, Dacryodes buettneri, Entandrophragma spp., Alstonia congensis and Funtumia elastica. Over time the species composition changes and eventually it becomes dense enough to suppress the Marantaceae, which do not survive in dense shade.

- A prominent feature of the rainforests in Africa is the presence of bands of pioneer or secondary forest along the road networks (Mayaux et al., 1999). The vegetation found along these routes is a complex of secondary regrowth, fallow, home gardens, food crops and village plantations (A1 and A2). Species of the Zingiberaceae also occur in clearings and along roads, especially Aframomum spp. and several Costus spp. (A3).

- Abandonment of deforested areas for settlements and planting of crops in the Mayoko region is not necessarily followed by succession to savanna/grassland. Deforestation is generally followed by rapid reforestation of typical secondary forests rather than savanna elements being introduced. Abandoned cropland is soon replaced with Musanga cecropioides (A2). In some instances, the abandoned cropland is invaded by introduced invasive species e.g. Chromolaena odorata, Lantana camara and Bambusa vulgaris (A2).

- Forest fallows of 1, 3, 4 and 7 years since abandonment were studied by Moutsambote et al. (2000). They recognized four successional stages with the first stage dominated by Chromolaena odorata, followed by Hymenocardia ulmoides, Harungana madagascariensis, Trema guineensis and Xylopia aethiopica after 3-4 years. More phanerophytes occur after seven years.

- It is noteworthy that the anthropogenic and highly disturbed associations (A1 - A3) were grouped together with wetland associations in cluster 1. It therefore appears that all associations (wetland as well as terra firme) when severely degraded are reduced to the same species poor assemblages. The successional pathways to the different associations are believed to radiate from this point (Figure 4).

Several recent publications commented on long-term effects of disturbances linked to human activities. Oslisly et al. (2013) contended that human-related disturbances over the past 2000 years could still have a bearing on results obtained currently on carbon stocks. Different processes occur at different rates and while the recovery of biomass and species richness may take only decades, 
the return to the original species composition should be measured in centuries (Chazdon, 2003; Marin-Spiotta et al., 2007). It should also be considered that even though species composition of primary and secondary forests differs, secondary forests still provide many of the same ecosystem services as primary forests. Although African tropical forests have been fairly resilient towards past human interference (Oslisly et al., 2013; Gourlet-Fleury et al., 2013; Rudel, 2013; Willis et al., 2004) these forests are currently facing new threats. Destruction of topsoil by mining activities will have severe long-lasting effects and intervention will be necessary for forest recovery. Active rehabilitation of mined sites should explore patterns of forest survival that allowed these forests to recover quickly in the past and attempt to recreate similar suitable conditions.

\subsection{Conclusion on Phytosociological Approach}

Despite opinions in disfavour of using phytosociological analysis of rainforest systems because of inherent complexity, costs and time requirements (Vande Weghe, 2004), the approach followed here proved remarkably robust in teasing out the levels of complexity that occur at local level in a topographically complex region of the Chaillu Massif. Although at individual association level, the sampling may have been limited and requires additional work, the data presentation in three subgroups provided a high level of insight into the possible dynamics of the forest association but also provided indications as to the possible successional pathways that may occur. This information is robust and provides a much better level of understanding of forest structure and evolution potential than studies limited to trees or to carbon remote sensing assessments or time change series. The authors believe the following aspects were key to the data quality and the insight obtained:

- The preliminary reconnaissance study allowed authors to develop a sampling frame based on a physiographic-physiognomic evaluation of vegetation types, presented as an initial investigation map.

- The multistage, stratified, semi-random sampling approach allowed a sampling pattern that was cost effective and provided further confidence for interpolation and extrapolation.

- A total of 235 sample plots were investigated. However, 191 plots was considered to be a reasonable target to attain the desired level of detail, provided that at least 20 plots were sampled per physiographic-physiognomic unit initially described.

- The use of many small plots was considered effective to provide an insight into variability, but also provided a rapid overview of locally "common" species.

The authors are of the opinion that such studies are highly valuable and benefits in terms of providing insights for vegetation dynamics as well as forming the base of the ecosystem assessment outweigh the potential costs in time and manpower. If a baseline study had to be reduced to its single most essential compo- 
nent (Gullison et al., 2015), the authors believe this approach would provide a highly valuable "default" overview of biodiversity complexity, structure and condition, as proposed in a preliminary manner by Pierson et al. (2015).

\section{Conflicts of Interest}

The authors declare no conflicts of interest regarding the publication of this paper.

\section{References}

Abernethy, K. A., Coad, L., Taylor, G., Lee, M. E., \& Maisels, F. (2013). Extent and Ecological Consequences of Hunting in Central African Rainforests in the Twenty-First Century. Philosophical Transactions of the Royal Society B, 368, Article ID: 20120303. https://doi.org/10.1098/rstb.2012.0303

Bourgeron, P. S., Humphries, H. C., \& Jensen, M. E. (2001). Representativeness Assessments. In M. E. Jensen, \& P. S. Bourgeron (Eds.), A Guidebook for Integrated Ecological Assessment (pp. 292-306). Berlin: Springer Verlag. https://doi.org/10.1007/978-1-4419-8620-7_21

Brewer, R., \& McCann, M. T. (1982). Laboratory and Field Manual of Ecology. Philadelphia: Saunders Publishing.

Chatelin, Y. (1968). Notes de pédologie gabonaise. 5. Géomorphologie et pédologie dans le sud Gabonais des Monts Birougou au littoral. Cahier ORSTOM, série Pédologie, 1, 3-20.

Chazdon, R. L. (2003). Tropical Forest Recovery: Legacies of Human Impact and Natural Disturbances. Perspectives in Ecology, Evolution and Systematics, 6, 51-71.

Colwell, R. K. (2013). Estimates: Statistical Estimation of Species Richness and Shared Species from Samples. Version 9. User's Guide and Application. http://purl.oclc.org/estimates

Corlett, R. T., \& Primack, R. B. (2011). Tropical Rain Forests: An Ecological and Biogeographical Comparison (2nd Edition, 326 p). Oxford: Wiley Blackwell. https://doi.org/10.1002/9781444392296

Damania, R., \& Wheeler, D. (2015). Road Improvement and Deforestation in the Congo Basin Countries. Policy Research Working Paper 7274. World Bank Group: Agriculture Global Practice Group.

Davidar, P., Rajagopall, B., Mohandass, D., Puyravaud, J.-P., Condit, R., Wright, S. J., \& Leigh, E. G. (2007). The Effect of Climatic Gradients, Topographic Variation and Species Traits on the Beta Diversity of Rain Forest Trees. Global Ecology and Biogeography, 16, 510-518. https://doi.org/10.1111/j.1466-8238.2007.00307.x

De Wasseige, C., De Marcken, P., Bayol, N., Hiol Hiol, F. Mayaux, P., Desclee, B., Nasi, R., Billand. A., Defourny, P., \& Ebaa Atyi, R. (Eds.) (2012). The Forests of the Congo Basin: State of the Forest 2012. Luxembourg: Publications Office of the European Union.

De Wasseige, C., Flynn, J., Louppe, D., Hiol Hiol, F., \& Mayaux, P. (2014). The Forests of the Congo Basin-Sate of the Forest (328 p). Belgium: Weyrich.

Edwards, D. P., Sloan, S., Weng, L., Dirks, P., Sayer, J., \& Laurance, W. F. (2014). Mining and the African Environment. Conservation Letters, 7, 302-311. https://doi.org/10.1111/conl.12076

ELLIOT, S., Blakesley, D., \& Hardwick, K. (2013). Restoring Tropical Forests: A Practical 
Guide (344 p). Kew: Royal Botanical Gardens.

Fisher, J. B., Sikka, M., Sitch, S., Ciais, P., Poulter, B., Galbraith, D., Lee, J.-E., Huntingford, C., Viovy, N., Zeng, N., Ahlstrom, A., Lomas, M. R., Levy, P. E., Frankenberg, C., Saatchi, S., \& Malhi, Y. (2013). African Tropical Rainforest Net Carbon Dioxide Fluxes in the Twentieth Century. Philosophical Transactions of the Royal Society B, 368, Article ID: 20120376. https://doi.org/10.1098/rstb.2012.0376

Gautam, S., \& Pietsch, S. A. (2012). Carbon Pools of an Intact Forest in Gabon. African Journal of Ecology, 50, 414-427. https://doi.org/10.1111/j.1365-2028.2012.01337.x

Gonmadje, C. F., Doumenge, C., Mckey, D., Tchouto, G. P. M., Sunderland, T. C. H., Balinga, M. P. B., \& Sonke, B. (2011). Tree Diversity and Conservation Value of Ngovayang's Lowland Forests, Cameroon. Biodiversity Conservation, 20, 2627-2648. https://doi.org/10.1007/s10531-011-0095-z

Gourlet-Fleury, S., Mortier, F., Fayolle, A., Baya, F., Ouédraogo, D., Bénédet, F., \& Picard, N. (2013). Tropical Forest Recovery from Logging: A 24 Year Silvicultural Experiment from Central Africa. Philosophical Transactions of the Royal Society B, 368, Article ID:20120302. https://doi.org/10.1098/rstb.2012.0302

Grunewald, K., \& Bastian, O. (2015). Ecosystem Services-Concept, Methods and Case Studies (312 p). Berlin: Springer Verlag. https://doi.org/10.1007/978-3-662-44143-5

Gullison, T., Hardner, J., Anstee, S., \& Meyer, M. (2015). Good Practices for the Collection of Biodiversity Baseline Data. Prepared for the Multilateral Financing Institutions Biodiversity Working Group \& Cross-Sector Biodiversity Initiative.

Hennekens, S. M., \& Schaminée, J. H. J. (2001). Turboveg, a Comprehensive Data Base Management System for Vegetation Data. Journal of Vegetation Science, 12, 589-591. https://doi.org/10.2307/3237010

Hund, K., Megevand, C., Mosnier, A., Hourtica, J., Sanders, K., Doetinchem, N., \& Streck, C. (2013). Deforestation Trends in the Congo Basin: Reconciling Economic Growth and Forest Protection. Washington DC: World Bank.

International Finance Corporation Performance Standard 6 Guidance Note. (2012). Biodiversity Conservation and Sustainable Management of Living Natural Resources. World Bank Group.

James, R., Washington, R., \& Rowell, D. P. (2013). Implications of Global Warming for the Climate of African Rainforests. Philosophical Transactions of the Royal Society B, 368, Article ID: 20120298. https://doi.org/10.1098/rstb.2012.0298

Kassi, N., Justin, K., \& Decocq, G. (2008). Successional Patterns of Plant Species and Community Diversity in a Semi-Deciduous Tropical Forest under Shifting Cultivation. Journal of Vegetation Science, 19, 809-820. https://doi.org/10.3170/2008-8-18453

Kent, M. (2012). Vegetation Description and Analysis: A Practical Approach (2nd Edition). Oxford: Wiley-Blackwell.

Lebamba, J., Ngomanda, A., Vincens, A., Jolly, D., Favier, C., Elenga, H., \& Bentaleb, I. (2009). Central African Biomes and Forest Succession Stages Derived from Modern Pollen Data and Plant Functional Types. Climate Past, 5, 403-429. https://doi.org/10.5194/cp-5-403-2009

Letouzey, R. (1968). Étude phytogéographique du Cameroun. Paris: Lechevalier.

Letouzey, R. (1985). Notice de la carte phytogéographique du Cameroun au 1/500,000. Toulouse, France: Institut de la carte international de la végétation.

Linder, H. P., Lovett, J., Mutke, J. M., Barthlott, W., Juergens, N., Rebelo, T., \& Kueper, W. (2005). A Numerical Re-Evaluation of the Sub-Saharan Phytochoria of Mainland Africa. Biologiske Skrifter, 55, 229-252. 
Lindsey, P. A., Balme, G., Becker, M., Begg, C., Bento, C., Bocchino, C., Dickman, A., Diggle, R. W., Eves, H., Henschel, P., \& Lewis, D. (2013). The Bushmeat Trade in African Savannas: Impacts, Drivers, and Possible Solutions. Biological Conservation, 160, 80-96. https://doi.org/10.1016/j.biocon.2012.12.020

Lovett, J. C., \& Wasser, S. K. (2008). Biogeography and Ecology of the Rain Forests of Eastern Africa (341 p). Cambridge: Cambridge University Press.

Maguran, A. E., \& Mcgill, B. J. (2011). Biological Diversity: Frontiers in Measurement and Assessment (345 p). Oxford: Oxford University Press.

Malhi, Y., Adu-Bredu, S., Asare, R. A., Lewis, S. L., \& Mayaux, P. (2013a). The Past, Present and Future of Africa's Rainforests. Philosophical Transactions of the Royal Society B, 368, Article ID: 20120293. https://doi.org/10.1098/rstb.2012.0293

Malhi, Y., Adu-Bredu, S., Asare, R. A., Lewis, S. L., \& Mayaux, P. (2013b). African Rainforests: Past, Present and Future. Philosophical Transactions of the Royal Society B, 368, Article ID: 20120312. https://doi.org/10.1098/rstb.2012.0312

Marin-Spiotta, E., Ostertag, R., \& Silver, W. L. (2007). Long-Term Patterns in Tropical Reforestation: Plant Community Composition and Biomass Accumulation. Ecological Applications, 17, 828-839. https://doi.org/10.1890/06-1268

Mayaux, P. (2004). A New Land-Cover Map of Africa for the Year 2000. Journal of Biogeography, 31, 861-877. https://doi.org/10.1111/j.1365-2699.2004.01073.x

Mayaux, P., Pekel, J.-F., Desclee, B., Donnay, F., Lupi, A., Achard, F., Clerici, M., Bodart, C., Brink, A., Nasi, R., \& Belward, A. (2013). State and Evolution of the African Rainforests between 1990 and 2010. Philosophical Transactions of the Royal Society B, 368, Article ID: 20120300. https://doi.org/10.1098/rstb.2012.0300

Mayaux, P., Richards, T., \& Janoder, E. (1999). A Vegetation Map of Central Africa Derived from Satellite Imagery. Journal of Biogeography, 25, 353-366.

https://doi.org/10.1046/j.1365-2699.1999.00270.x

Mbete, R. A., Banga-Mboko, H., Racey, P., Mfoukou-Ntsakala, A., Nganga, I., Vermeulen, C., Doucet, J.-L., Hornick, J.-L., \& Leroy, P. (2011). Household Bushmeat Consumption in Brazzaville, the Republic of the Congo. Tropical Conservation Science, 4, 187-202. https://doi.org/10.1177/194008291100400207

McCune, B., \& Grace, J. B. (2002). Analysis of Ecological Communities. Oregon: MjM Software Design, Gleneden Beach.

McCune, B., \& Mefford, M. J. (2011). PC-ORD. Multivariate Analysis of Ecological Data. Version 6. Oregon, USA: MjM Software, Gleneden Beach.

Moreno, C. E., \& Halffter, G. (2000). Assessing the Completeness of Bat Biodiversity Inventories Using Species Accumulation Curves. Journal of Applied Ecology, 37, 149-158. https://doi.org/10.1046/j.1365-2664.2000.00483.x

Moutsamboté, J. M., N’zala, D., \& Ngondo, J. C. (2000). Development of Forest Regrowth after Cassava Culture in Mayombe (Congo). Cahiers Agricultures, 9, 141-144.

Mueller-Dombois, D., \& Ellenberg, H. (1974). Aims and Methods of Vegetation Ecology. New York: Wiley.

Newton, A. C. (2007). Forest Ecology and Conservation, a Handbook of Techniques. Oxford, UK: Oxford University Press.

https://doi.org/10.1093/acprof:oso/9780198567448.001.0001

Oslisly, R., White, L., Bentaleb, I., Favier, C., Fontugne, M., Gillet, J.-F., \& Sebag, D. (2013). Climatic and Cultural Changes in the West Congo Basin Forests over the Past 5000 Years. Philosophical Transactions of the Royal Society B, 368, Article ID: 20120304. https://doi.org/10.1098/rstb.2012.0304 
Pierson, J. C., Barton, P. S., Lane, P. W., \& Lindenmayer, D. B. (2015). Can Habitat Surrogates Predict the Response of Target Species to Landscape Change? Biological Conservation, 184, 1-10. https://doi.org/10.1016/j.biocon.2014.12.017

Pilgrim, J. D., Brownlie, S., Ekstrom, J. M. M., Gardner, T., Von Hase, A., Kate, K. T., Savy, C. E., Stephens, R. T. T., Temple, H., Treweek, J., Ussher, G. T., \& Ward, G. (2013). A Process for Assessing the Offsetability of Biodiversity Impacts. Conservation Letters, 6, 376-384. https://doi.org/10.1111/conl.12002

Podani, J. (2001). Syn-Tax 2000 Computer Programs for Data Analysis in Ecology and Systematic. Budapest: Scientia Publishing.

Raaijmakers, J. G. W. (1987). Statistical Analysis of the Michaelis-Menten Equation. Biometrics, 43, 793-803. https://doi.org/10.2307/2531533

Rudel, T. K. (2013). The National Determinants of Deforestation in Sub-Saharan Africa. Philosophical Transactions of the Royal Society B, 368, Article ID: 20120405. https://doi.org/10.1098/rstb.2012.0405

Senterre, B., \& Lejoly, J. (2001). Trees Diversity in the Nsork Rain Forest (Rio Muni, Equatorial Guinea). Acta Botanica Gallica: Botany Letters, 148, 227-235. https://doi.org/10.1080/12538078.2001.10515890

Senterre, B., Lejoly, J., \& Sonké, B. (2004). Analyse du gradient de continentalité et identification de communautés végétales en forêts denses d'Afrique centrale par la méthode du mega-transect. Phytocoelogia, 34, 490-515.

https://doi.org/10.1127/0340-269X/2004/0034-0491

Soberôn, J., \& Llorente, J. (1993). The Use of Species Accumulation Functions for the Prediction of Species Richness. Conservation Biology, 7, 480-488.

https://doi.org/10.1046/j.1523-1739.1993.07030480.x

Tchouto, M. G. P., De Boer, W. F., De Wilde, J. J. F. E., \& Van der Maesen, L. J. G. (2005). Diversity Patterns in the Flora of the Campo-Ma'an Rain Forest, Cameroon: Do Tree Species Tell it All? Biodiversity \& Conservation, 15, 1353-1374. https://doi.org/10.1007/s10531-005-5394-9

Tichy, L. (2002). JUICE, Software for Vegetation Classification. Journal of Vegetation Science, 13, 451-453. https://doi.org/10.1111/j.1654-1103.2002.tb02069.x

Van Der Maarel, E. (2007). Transformation of Cover-Abundance Values for Appropriate Numerical Treatment-Alternatives to the Proposals by Podani. Journal of Vegetation Science, 18, 767-770.

Van Rooyen, M., Van Rooyen, N., Orban, B., Nsongola, G., Miabanga, E. S., \& Gaugris, J. (2017). Floristic Composition, Diversity and Structure of the Forest Communities in the Kouilou Département, Republic of Congo. Tropical Ecology, 57, 805-824.

Vande Weghe, J.-P. (2004). Forests of Central Africa. Nature and Man (365 p). Tielt, Belgique: Lanoo Publishers.

Werger, M. J. A. (1974). On Concepts and Techniques Applied in the Zurich-Montpellier Method of Vegetation Survey. Bothalia, 11, 309-323. https://doi.org/10.4102/abc.v11i3.1477

White, F. (1979). The Guineo-Congolian Region and its Relationships to Other Phytochoria. Bulletin du Jardin Botanique National Belge, 49, 11-55. https://doi.org/10.2307/3667815

White, F. (1983). The Vegetation of Africa. Paris: UNESCO/AETFAT/UNSO.

Willis, K. J., Bennett, K. D., Burrough, S. L., Macias-Fauria, M., \& Tovar, C. (2013). Determining the Response of African biota to Climate Change: Using the Past to Model the Future. Philosophical Transactions of the Royal Society B, 368, Article ID: 
20120491. https://doi.org/10.1098/rstb.2012.0491

Willis, K. J., Gillson, L., \& Nrncic, T. M. (2004). How “Virgin” Are Virgin Rainforest? Science, 304, 402-403. https://doi.org/10.1126/science.1093991

Wilson, M. C., Chen, X.-Y., Corlett, R. T., Didham, R. K., Ding, P., Holt, R. D., Holyoak, M., Hu, G., Hughes, A. C., Lin, J., Laurance, W. F., Liu, J., Pimm, S. L., Robinson, S. K., Russo, S. E., Si, X., Wilcove, D. S., Wu, J., \& Yu, M. (2016). Habitat Fragmentation and Biodiversity Conservation: Key Findings and Future Challenges. Landscape Ecology, 31, 219-227. https://doi.org/10.1007/s10980-015-0312-3 


\section{Supplementary Material}

\section{Appendix A. Synoptic Table for the Mayoko Study Area, Republic of Congo}

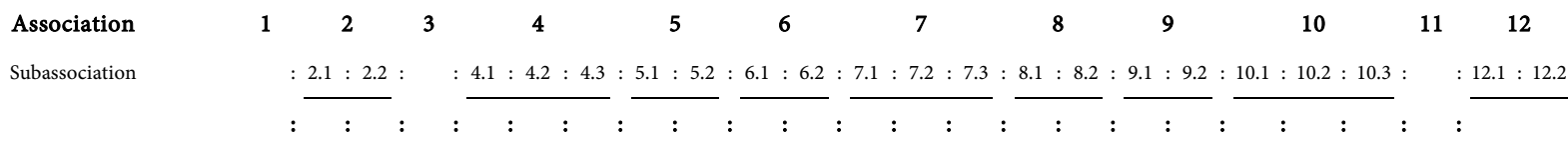

\begin{tabular}{|c|c|c|c|}
\hline Species group A & : & : & $:$ \\
\hline Erythrina species & $5:$ & : & : \\
\hline Mangifera indica $L$ & $5:$ & : & : \\
\hline Caladium bicolor (Aiton) Vent. & $5:$ & : & : \\
\hline Dacryodes edulis (G.Don) H.J.Lam & $5:$ & : & $:$ \\
\hline Cola nitida (Vent.) Schott \& Endl. & $5:$ & : & : \\
\hline Persea americana Mill & $5:$ & : & : \\
\hline Ananas comosus (L.) Merr. & $5:$ & : & $:$ \\
\hline Pollia condensata C.B.Clarke & $5:$ & : & $:$ \\
\hline Musa paradisiaca L. & $5:$ & : & : \\
\hline Species group B & : & : & : \\
\hline Pteridium aquilinum (L.) Kuhn & : & $: 5$ & ;: \\
\hline Smilax anceps Willd. & : & $: 3$ & : \\
\hline Lantana camara L. & : & $: 3$ & : \\
\hline $\begin{array}{l}\text { Setaria megaphylla (Steud.) } \\
\text { T.Durand \& Schinz }\end{array}$ & & $: 3$ & : \\
\hline Cogniauxia podolaena Baill. & : & 3 & : \\
\hline $\begin{array}{l}\text { Aframomum alboviolaceum (Ridl.) } \\
\text { K.Schum. }\end{array}$ & & $: 3$ & $:$ \\
\hline $\begin{array}{l}\text { Chromolaena odorata (L.) } \\
\text { R.M.King \& H.Rob. }\end{array}$ & $5:$ & $: 3$ & : \\
\hline $\begin{array}{l}\text { Albizia adianthifolia (Schumach.) } \\
\text { W.Wright }\end{array}$ & & $: 2$ & : \\
\hline $\begin{array}{l}\text { Morinda morindoides (Baker) } \\
\text { Milne }\end{array}$ & & $: 2$ & : \\
\hline Ipomoea mauritiana Jacq. & : & $: 2$ & $:$ \\
\hline $\begin{array}{l}\text { Megastachia mucronata (Poir.) } \\
\text { P.Beauv. }\end{array}$ & & 2 & : \\
\hline
\end{tabular}

Species group C

Anthocleista schweinfurthii Gilg.

Vernonia conferta Benth.

Species group D

Scleria secans (L.) Urb.

Clappertonia polyandra (K. Schum. ex Sprague) Bech

Setaria sphacelata (Schumach.) Stapf \& C.E.Hubb. ex M.B.Moss var. sphacelata

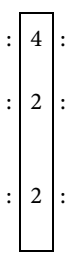

Species group E 


\section{Continued}

Mucuna flagellipes Hook.f.

Triumfetta cordifolia A.Rich.

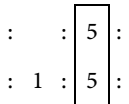

Species group $\mathrm{F}$

Triumfetta rhomboidea Jacq.

Aphanostylis species

Alstonia congensis Engl.

Species group G

Cyperus pectinatus Vahl

Leersia hexandra Sw.

Ottelia ulvifolia (Planch.) Walp.

Ceratophyllum demersum L.

Scleria boivinii Steud.

Sterculia subviolacea K.Schum

Azolla pinnata R.Br.

Cathormion altissimum (Hook.f) Hutch. \& Dandy

Ludwigia adscendens L.Hara

Alstonia boonei De Wild.

Panicum brevifolium L.

Cryptolepis oblongifolia (Meisn.) Benth.

Dalbergia letestui

\section{Species group $\mathrm{H}$}

Rhynchospora corymbosa (L.) Britton

Voacanga thouarsii Roem. \& Schult.

Lygodium microphyllum (Cav.) R.Brown

Elaeis guineensis Jacq.

Fuirena umbellata Rottb.

\section{Species group I}

Anthocleista vogelii Planch.

Acroceras zizanioides Dandy

Scleria racemosa Poir.

Ludwigia abyssinica A. Rich.

\section{Species group J}

Dichaetanthera strigosa (Cogn.) Jacq.-Fél.

Lycopodiella cernua (L.) Pic. Serm. Aframomum citratum (J.Pereira) K.Schum.

Ipomoea involucrata P.Beauv. 


\section{Continued}

Heterotis rotundifolia (Sm.) Triana

Panicum parvifolium Lam.

Species group $\mathrm{K}$

Harungana madagascariensis Lam. ex Poir.

\section{Species group L}

Gilbertiodendron ogoouense (Pellegr.) J.Léonard

Gilbertiodendron dewevrei (De Wild.) J.Léonard

Antidesma laciniatum Müll.Arg.

Treculia africana Decne. subsp. africana var. africana

Argocoffeopsis eketensis

(Wernham) Robbr.

Martretia quadricornis Beille

\section{Species group $M$}

Carapa procera DC. var. palustre

Microcos coriacea (Mast.) Burret

Pterygota bequaertii De Wild.

Leea guineensis Müll.Arg.

Ceiba pentandra (L.) Gaertn.

Leptonychia batangensis (C.H.Wright) Burret

Anubias afzelii Schott

Combretum racemosum P.Beauv.

Recktophyllum cameroonensis

Piper guineense Schum. \& Thonn.

\section{Species group $\mathrm{N}$}

Berlinia bracteosa Benth.

Millettia griffoniana Baill.

Species group $\mathrm{O}$

Xylopia rubescens Oliv. var. rubescens

Raphia vinifera P.Beauv.

Christella dentata (Forssk.)

Holttum

Gardenia imperialis K.Schum.

Microsorium punctatum (L.)

Copel.

Bridelia micrantha (Hochst.) Baill. 5

\section{Species group $P$}

Costus lucanusianus J.Braun \& K.Schum. var. lucanusianus
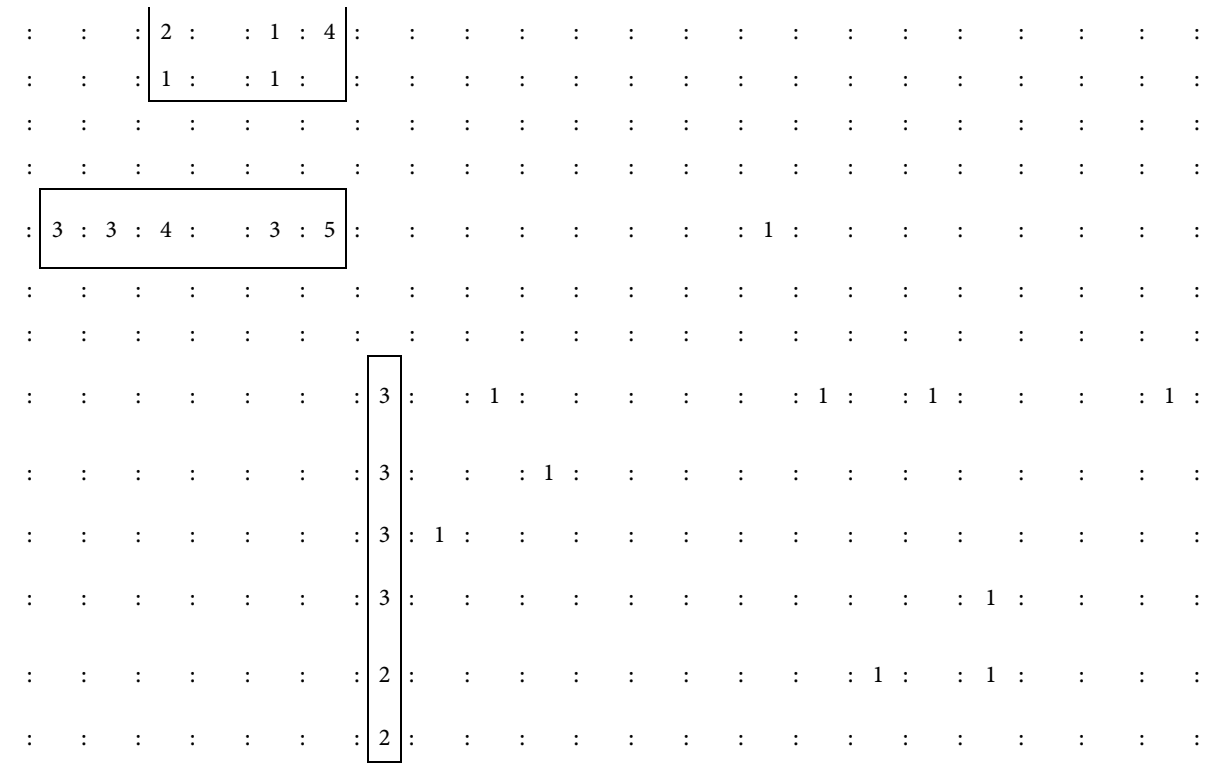

1

$1:$

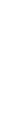




\section{Continued}

\section{Species group $Q$}

Begonia elatostemmoides Hook.f Cola attiensis Aubrév. \& Pellegr. Monodora myristica (Gaertn.) Dunal

Begonia ampla Hook.f.

Cyathea manniana Hook.

Dracaena camerooniana Baker

\section{Species group $\mathbf{R}$}

Sterculia tragacantha Lindl.

Leptoderris hypargyrea Dunn

Culcasia angolensis Welw. ex Schott

Acanthaceae species

Raphia hookeri G.Mann \& H.Wendl.

Maprounea membranacea Pax \& K.Hoffm.

Irvingia grandifolia (Engl.) Engl.

Vernonia titanophylla Brenan

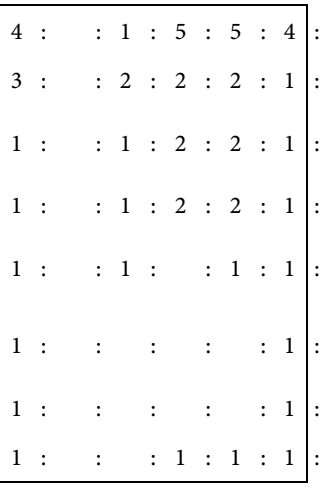

\section{Species group $S$}

Marattia fraxinea Sm.

Begonia microsperma Warb.

Ataenidia conferta (Benth.) Milne-Redh.

Cyathea camerooniana Hook.

Impatiens irvingii Hook.f.

Hypolytrum heteromorphum Nelmes

Monanthotaxis species

Anubias lanceolata N.E.Br.

Begonia fusialata Warb.

Species group $\mathrm{T}$

Cnestis ferruginea DC

Ancistrocarpus densispinosus Oliv.

Acacia kamerunensis Gand

Phyllanthus polyanthus Pax

Asparagus drepanophyllus Welw. ex Baker

Desmodium adscendens (Sw.) DC.

Dichapetalum flaviflorum Engl.

Monodora angolensis Welw.

Glyphaea brevis (Spreng.) Monach.

Dioscorea bulbifera L. 


\section{Continued}

Standfieldiella imperforata (C.B. Clarke) Brenan

Caloncoba welwitschii (Oliv.) Gilg Odyendyea gabonensis (Pierre) Engl.

Drypetes paxii Hutch.

Aframomum sericeum Dhetchuvi \& D.J. Harris

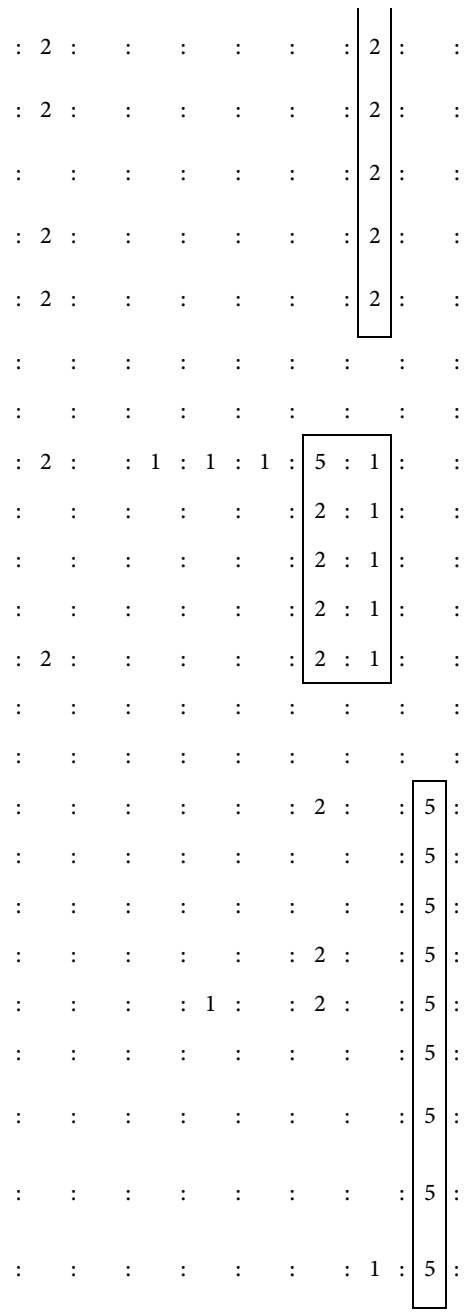

\section{Species group U}

Palisota schweinfurthii C.B.Clarke

Leptaspis comorensis A.Camus

Cercestis mirabilis (Gilg) Jacq.-Fél.

Lomariopsis hederacea Alston

Renealmia polypus Gagnep.

Species group V

Penianthus longifolius Miers

Triclisia patens Oliv.

Carpolobia lutea G.Don

Pancovia pedicellaris Radlk. \& Gilg

Dialium polyanthum Harms

Olax subcorpioidea Oliv.

Synsepalum longecuneatum De Wild.

Trichilia heudelotii Planch. ex

Oliv.

Rourea coccinea (Schumach. \&

Thonn.) Hook.f.

\section{Species group $\mathrm{W}$}

Eremospatha korthalsiifolia Becc.

Lonchitis currori (Hook.) Mett.

Agelaea villosiflora Schellenb.

Ctenitis protensa (Afzel. ex Sw.)

Ching

Podococcus acaulis Hua

Corynanthe mayumbensis (R.D.Good).N.Halle

Afrocalathea rhizantha (K.Schum.) K.Schum.

Connarus griffonianus Baill. Caloncoba glauca (P.Beauv.) Gilg Alchornea hirtella Benth.

Rauvolfia mannii Stapf

Pauridiantha mayumbensis (R.D.Good) Bremek.

Campylospermum laeve Farron Rytigynia dewevrei (De Wild. \& T.Durand) Robyns 


\section{Continued}

Cola heterophylla (P.Beauv.) Schott \& Endl.

Myrianthus serratus (Trecul) Benth. \& Hook.

Mapania mannii C.B.Clarke

Pachypodanthium staudtsii (Engl. \& Diels) Engl. \& Diels

Memecylon zenkeri Gilg

Funtumia elastica Stapf

Thomandersia laurifolia

(T.Anderson ex Benth.) Baill.

\section{Species group $\mathbf{X}$}

Hallea stipulosa (DC.) Leroy

Macaranga schweinfurthii Pax

Sarcocephalus pobeguinii Pobeg.

Halopegia azurea (K.Schum.)

K.Schum.

Selaginella versicolor Spring

Brenania brieyi (De Wild.) Petit

Campylospermum elongatum

(Oliv.) Tiegh.

Clitandra cymulosa Benth.

Angylocalyx boutiqueanus Touss.

Cercestis kamerunianus (Engl.)

N.E.Br.

Species group $\mathrm{Y}$

Pseudospondias microcarpa

(A.Rich.) Engl.

Hypselodelphys scandens Louis \& Mullend.

Aframomum species
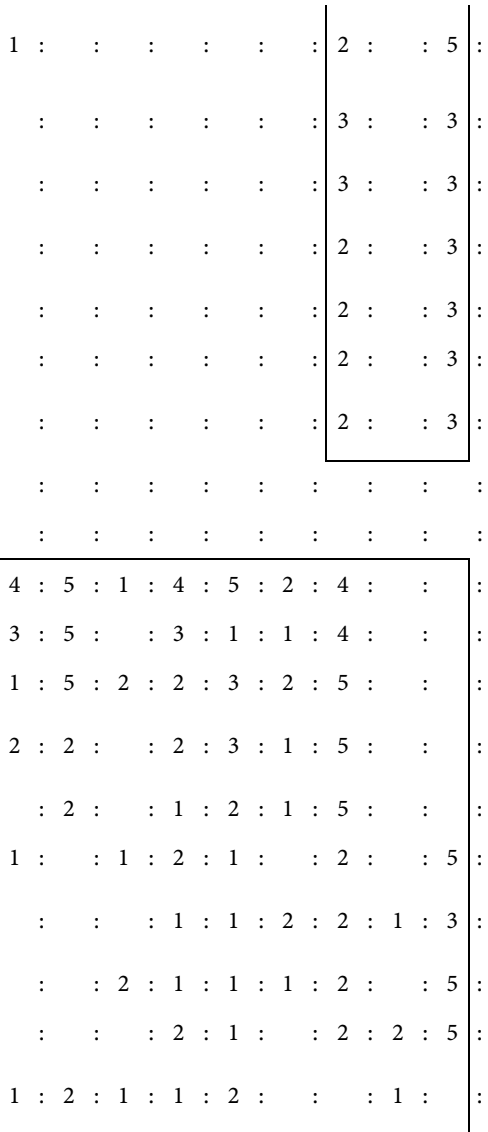

\section{Species group $\mathrm{Z}$}

Selaginella myosurus (Sw.) Alston

Nephrolepis biserrata (Sw.) Schott 5

Dinophora spenneroides Benth.

Alchornea cordifolia (Schumach. \& Thonn.) Müll.Arg.

Macaranga monandra Müll.Arg.

Costus afer Ker Gawl.

Eremospatha cabrae (T.Durand \& Schinz) De Wild.

$: \begin{array}{llllllllllllllllllllll}1 & : & : & 4 & : & : & 5 & : & 5 & : & : & 1 & : & 1 & : & 1 & : & 2 & : & 2 \\ 3 & : & : & : & : & 5 & : & 5 & : & 2 & : & 2 & : & 1 & : & 2 & : & 3 & : & 1 \\ : & : & : & 5 & : & : & : & 4 & : & : & : & : & : & 2 & : & 2 \\ 3 & : & : & : & 3 & : & 2 & : & 4 & : & : & : & : & : & 2 & : & 1 \\ : & 3 & : & 2 & : & : & 1 & : & 2 & : & : & 2 & : & 1 & : & 1 & : & : & : & 2 \\ 3 & : & : & 1 & : & : & 1 & : & 4 & : & : & 1 & : & 1 & : & : & 3 & : & 3 \\ 2 & : & : & : & : & : & : & 1 & : & : & 1 & : & : & 2 & : & 1\end{array}::$

Species group AA

Hymenocardia ulmoides Oliv.

Maesobotrya species

Zanthoxylon gilletii (De Wild.)

P.G.Waterman

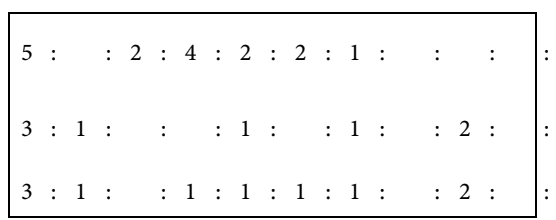




\section{Continued}

Meldinia species

Tricalysia species

Species group AB

Syzygium species

Aporrhiza species

Pseudospondias longifolia Engl.

Scorodophloeus zenkeri (Engl.)

Exell \& Mendonça

Funtumia africana (Benth.) Stapf

Species group AC

Sarcophrynium

schweinfurthianum (Kuntze)

Milne-Redh.

\section{Species group AD}

Grewia conocarpa K. Schum.

Vepris louisii G.Gilbert

Rothmannia octomera (Hook.)

Fagerl.

Testulea gabonensis Pellegr.

Librevillea klainei (Pierre ex

Harms) Hoyle

Irvingia robur Mildbr.

Tricalysia pallens Hiern

Dialium dinklagei Harms

Hannoa silvestris Cheek \&

Jongkind

Pentadesma butyracea Sabine

Carpolobia alba G.Don

Heisteria zimmereri Engl.

Aubrevillea platycarpa Pellegr.

Voacanga chalotiana Pierre ex Stapf

Dacryodes species

Olyra latifolia L.

Dalbergia fouilloyana Pellegr.

Massularia acuminata (G.Don) Bullock ex Hoyle

Newtonia devredii G.C.C.Gilbert \& Boutique

Campylospermum excavatum

(Tiegh.) Farron

Chlamydocola chlamydantha

(K.Schum.) M.Bodard

Species group $\mathrm{AE}$

Geophila repens (L.) I.M.Johnst.

Ardisia species

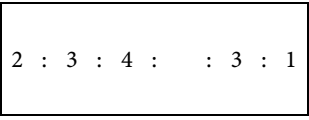




\section{Continued}

Hymenocoleus hirsutus (Benth.) Robbr.

Irvingia gabonensis

(Aubry-LeComte ex O'Rorke)

Baill.

Palisota hirsuta (Thunb.)

K.Schum.

Grewia oligoneura Sprague

Craterispermum laurinum (Poir.) Benth.

Ricinodendron heudelotii (Baill.)

Pierre ex Heckel

Eremospatha haullevilleana De Wild.

Garcinia kola Heckel

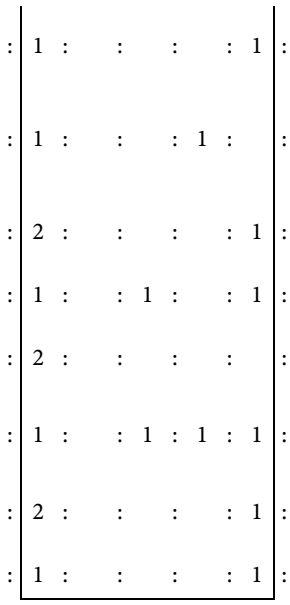

Species group AF

Mostuea species

Species group AG

Scaphopetalum zenkeri K.Schum.

Antrocaryon micraster A.Chev. \& Guillaumin

Oxyanthus speciosus DC.

Diospyros species

Tiliacora funifera (Miers) Oliv.

Trichilia gilgiana Harms

Rothmannia whitfieldii (Lindl.)

Dandy

Mostuea hirsuta (Benth. \&

Hook.f.) Baill. ex Baker

Rothmannia talbotii (Wernham)

Keay

Cleistopholis glauca Pierre ex Engl. \& Diels

\section{Species group $\mathrm{AH}$}

Angylocalyx pynaertii De Wild.

Grewia species

Strychnos camptoneura Gilg \& Busse

Thomandersia congolana De Wild. \& T.Durand

Chytranthus talbotii (Baker f.)

Keay

Trichoscypha species

Orthopichonia schweinfurthii

(Stapf) H. Huber

Sorindeia species

Begonia species
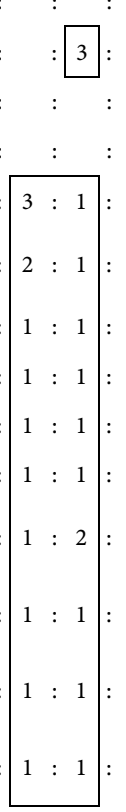


\section{Continued}

Species group AI

Aphanocalyx microphyllus (Harms) Wieringa

Eremospatha quinquecostulata Becc.

Lasianthus batangensis K.Schum.

Croton haumanianus J.Léonard

Bertiera racemosa (G.Don)

K.Schum. var. racemosa

Tetrorchidium didymostemon (Baill.) Pax \& K.Hoffm.

Agelaea palmata Jongkind

Pancovia laurentii (De Wild.) Gilg ex De Wild.

Macaranga spinosa Müll.Arg

Marantochloa monophylla

(K.Schum.) D’Orey

\section{Species group AJ}

Bolbitis gaboonensis (Hook.)

Alston

Engomegoma gordonii Breteler

Thaumatococcus daniellii (Bennet) Benth.

Magnistipula tessmannii (Engl.)

Prance

Pachypodanthium confine Engl. \& Diels

Manilkara species

Brazzeia congoensis Baill.

\section{Species group AK}

Xylopia quintasii Engl. \& Diels

Strombosiopsis tetrandra Engl.

Quassia africana (Baill.) Baill.

Mostuea brunonis Didr. var.

brunonis

Chrysophyllum species

Garcinia smeathmannii (Planch. \& Triana) Oliv.

\section{Species group AL}

Dacryodes macrophylla (Oliv.)

H.J.Lam

Dacryodes buettneri (Engl.)

H.J.Lam

Amphimas ferrugineus Pierre ex Pellegr.

Picralima nitida (Stapf) T.Durand \& H.Durand

Salacia lehmbachii Loes. var. lehmbachii
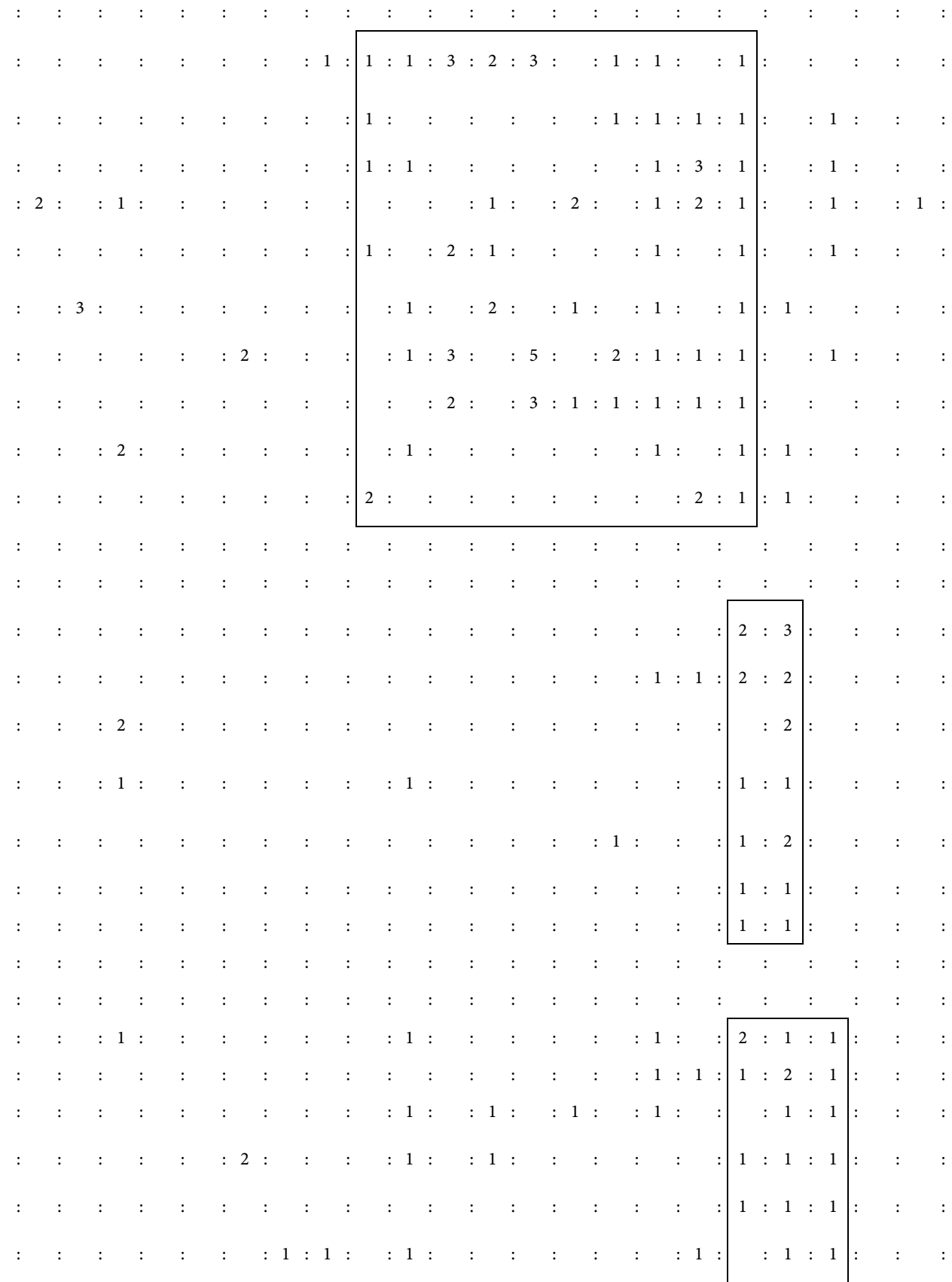


\section{Continued}

Garcinia punctata Oliv.

Turraeanthus africanus (Welw. ex C.DC.) Pellegr.

Annickia chlorantha Oliv.

Barteria dewevrei De Wild. \&

T.Durand

Oncoba welwitschii Oliv.

Fougere

Dioncophyllum thollonii Baill.

Aoranthe cladantha (K.Schum.) Somers

Species group AM

Raphia regalis Becc.

Agelaea poggeana Gilg

Rinorea species

Dialium tessmannii Harms

Bosqueiopsis gilletii De Wild. \& T.Durand

Drypetes species

Pausinystalia macroceras vel. aff. (K. Schum.) Pierre ex Bielle

Maranthes glabra (Oliv.) Prance

Podococcus barteri G.Mann \& H.Wendl.

\section{Species group AN}

Rothmannia hispida (K.Schum.) Fagerlind

Megaphrynium macrostachyum (Benth.) Milne-Redh.

Diospyros hoyleana F.White

Manotes expansa Sol. ex Planch.

Cola digitata Mast.

Grewia seretii De Wild.

Baissea axillaris (Benth.) Hua

Thomandersia hensii De Wild. \& T.Durand

Tetrapleura tetraptera (Schumach. \& Thonn.) Taub.

Icacina mannii Oliv.

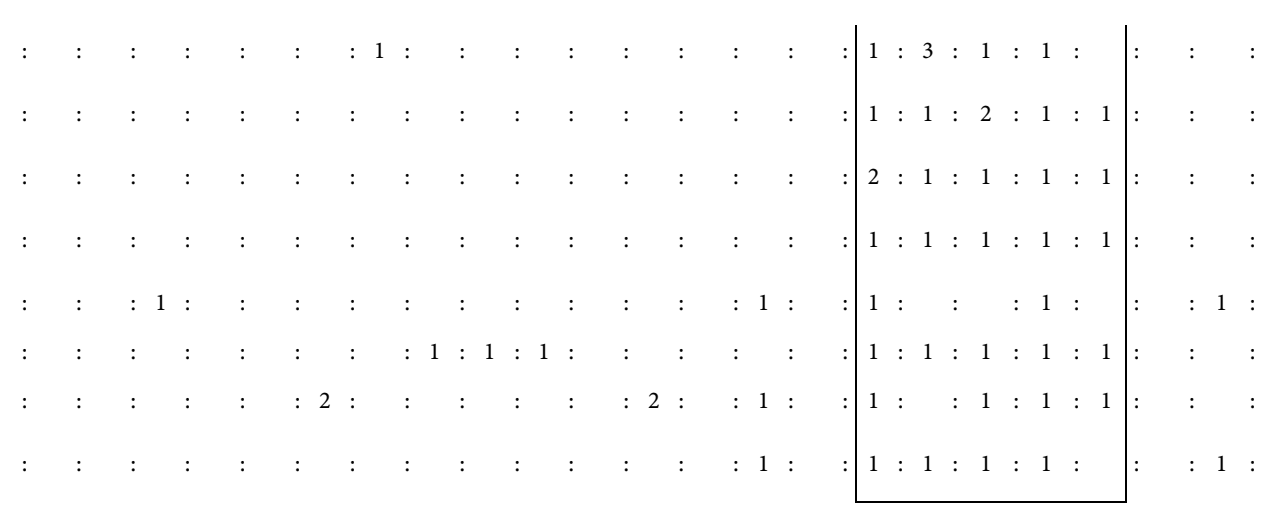




\section{Continued}

Costus species

Oxyanthus schumannianus De Wild. \& T.Durand

Salacia erecta (G.Don) Walp. var. erecta

Maesobotrya barteri (Baill.) Hutch.

Palisota mannii C.B.Clarke

Quassia gabonensis Pierre

Homalium africanum (Hook.f.)

Benth.

\section{Species group AP}

Musanga cecropioides R.Br.

\section{Species group AQ}

Vitex doniana Sweet

Microdesmis camerunensis J.Léonard

Rourea obliquifoliolata Gilg

Anisophyllea purpurascens Hutch. \& Dalziel

Dalhousiea africana S.Moore

Parkia bicolor A.Chev.

Landolphia ligustrifolia (Stapf) Pichon

Scaphopetalum blackii Mast.

Sarcophrynium prionogonium (K.Schum.) K.Schum.

Trichoscypha acuminata Engl.

Palisota satabiei Brenan

Hylodendron gabunense Taub.

Warneckea membranifolia (Hook. f.) Jacq.-Fél.

Medinilla mirabilis (Gilg) Jacq.-Fél.

Afrostyrax lepidophyllus Mildbr. Pauridiantha dewevrei (De Wild. \& T.Durand) Bremek.

Hugonia platysepala Welw. ex Oliv.

Cnestis corniculata Lam.

Olax gambecola Baill.

Gnetum africanum Welw.

Chythranthus atroviolaceus Baker f. ex Hutch. \& Dalziel

Erythrophloeum suaveolens (Guill. \& Perr.) Brenan

Xylopia africana (Benth.) Oliv

Aidia micrantha (K.Schum.)

F.White

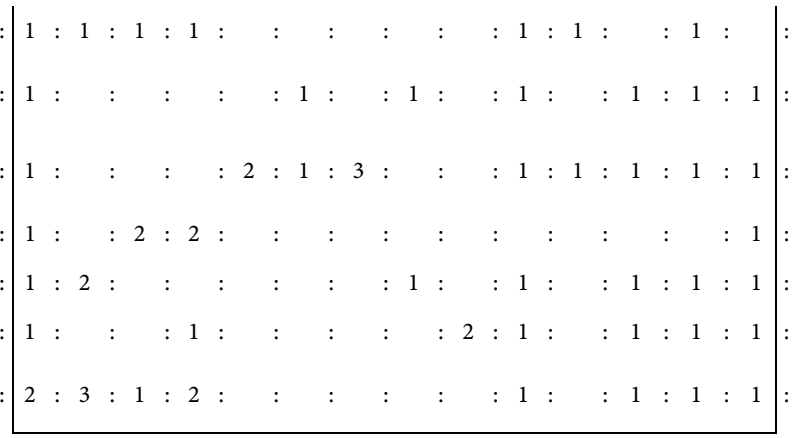

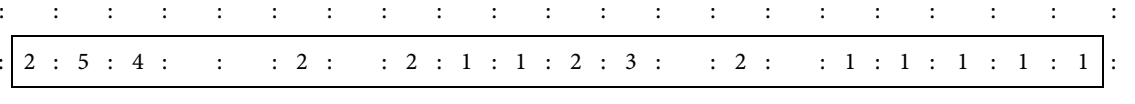




\section{Continued}

Species group AR

Trachyphrynium braunianum (K.Schum.) Baker

Leptaspis zeylanica Nees ex Steud. Geophila afzelii Hiern

Marantochloa conferta (Benth.) A.C.Ley

Strombosia grandifolia Hook.f.

Sclerosperma mannii H.Wendl.

Eremospatha macrocarpa Bocq.

Agelaea paradoxa Gilg

Xylopia staudtii Engl. \& Diels

Anonidium mannii (Oliv.) Engl. \&

Diels

Desbordesia glaucescens (Engl.)

Tiegh.

Garcinia species

Pterocarpus soyauxii Taub.

Trilepisium madagascariense DC.

\section{Species group AS}

Tabernaemontana crassa Benth.

Maesobotrya klaineana (Pierre) J.Léonard

Eriocoelum microspermum Gilg ex Radlk.

Renealmia congoensis Gagnep.

Laccosperma laeve (G. Mann \& H. Wendl.) Wendl.

Manniophyton fulvum Müll.Arg.

Trichilia monadelpha (Thonn.) J.J.de Wilde

Bobgunnia fistuloides (Harms) J.H.Kirkbr. \& Wiersema

\section{Species group AT}

Agelaea pentagyna (Lam.) Baill.

Guaduella oblonga Hutch. ex Clayton

Palisota ambigua (P.Beauv.) C.B.Clarke

Neuropeltis velutina Hallier $\mathrm{f}$.

Laccosperma secundiflorum (P.Beauv.) Kuntze

Tetracera potatoria Afzel. ex G.Don

Dichapetalum brazzae Pellegr.

Microdesmis puberula Hook.f. ex Planch.

Species group AU 


\section{Continued}

Alchornea floribunda Oliv.

Eremospatha wendlandiana Dammer ex Becc.

Anthonotha macrophylla P.Beauv. 5

Oncoba glauca (P.Beauv.) Planch.

Dioscorea smilacifolia De Wild.

Marantochloa congensis Engl.

Cleistopholis patens (Benth.) Engl. \& Diels

\section{Species group AV}

Engomegoma gordonii Breteler

\section{Species group AW}

Dacryodes pubescens (Vermoesen) H.J.Lam

Duboscia macrocarpa Bocq.

Staudtia kamerunensis Warb. var. gabonensis Fouilloy

Xylopia hypolampra Mildbr.

Chrysophyllum lacourtianum De Wild.

Allanblackia floribunda Oliv.

Canarium schweinfurthii Engl.

Cylicodiscus gabunensis Harms

Diogoa zenkeri (Engl.) Exell \&

Mendonça

Ongokea gore (Hua) Pierre

Guarea cedrata (A.Chev.) Pellegr.

Barteria fistulosa Mast.

\section{Species group $\mathrm{AX}$}

Shirakiopsis elliptica (Hochst.)

Esser

Greenwayodendron suaveolens Engl. \& Diels

Pentaclethra eetveldeana De Wild. \& T.Durand

Santiria trimera (Oliv.) Aubrév.

Celtis adolfi-friderici Engl.

Heisteria parvifolia Sm.

Myrianthus preussii subsp. seretii (De Wild.) Ruiter

Treculia obovoidea N.E.Br.

Strombosia pustulata Oliv.

Albizia zygia (DC.) J.F.Macbr.

\section{Species group AY}

Coelocaryon preussii Warb.
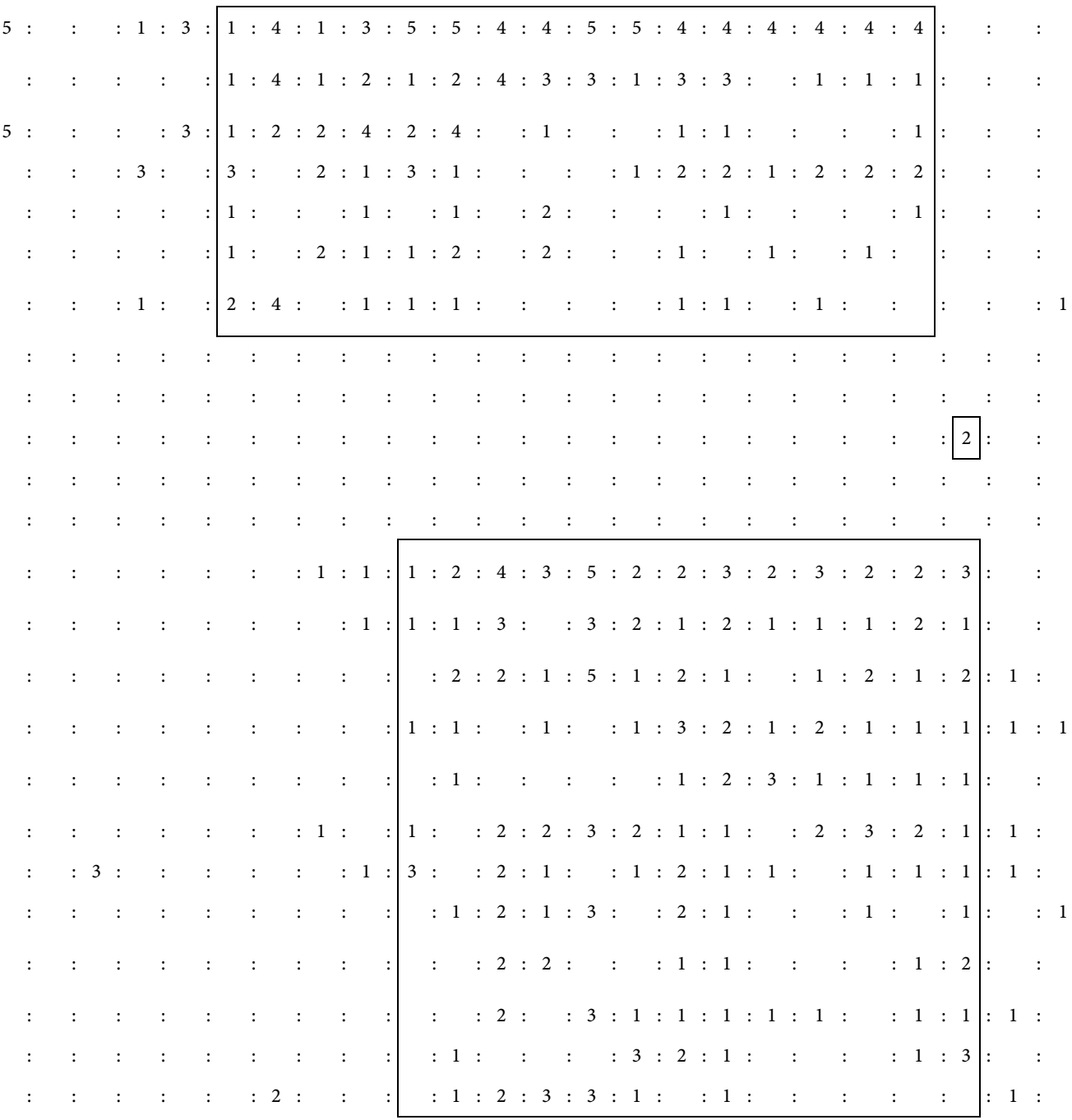

\section{Continued}




\section{Continued}

Plagiostyles africana (Müll.Arg.) Prain

Petersianthus macrocarpus (P.Beauv.) Liben

Piptadeniastrum africanum (Hook.f.) Brenan

Distemonanthus benthamianus Baill.

Dialium pachyphyllum Harms

Klainedoxa gabonensis Pierre

Species group AZ

Uapaca guineensis Müll.Arg.

Symphonia globulifera L.f.

\section{Species group BA}

Aucoumea klaineana Pierre

Xylopia aethiopica (Dunal) A.Rich. Dichostemma glaucescens Pierre Carapa procera DC. var. procera Albizia ferruginea (Guill. \& Perr.) Benth.

Zanthoxylum heitzii (Aubrév. \& Pellegr.) P.G.Waterman

\section{Species group BB}

Pycnanthus angolensis (Welw.) Warb.

Pentaclethra macrophylla Benth.

\section{Species group BC}

Coelocaryon botryoides

Vermoesen

Macaranga barteri Muell.Arg.

Marantochloa purpurea (Ridl.) Milne-Redh.

Myrianthus arboreus P.Beauv.

Aframomum longipetiolatum Koechlin

Emilia coccinea (Sims) G.Don

Morinda lucida Benth.

Dalbergia hostilis Benth.
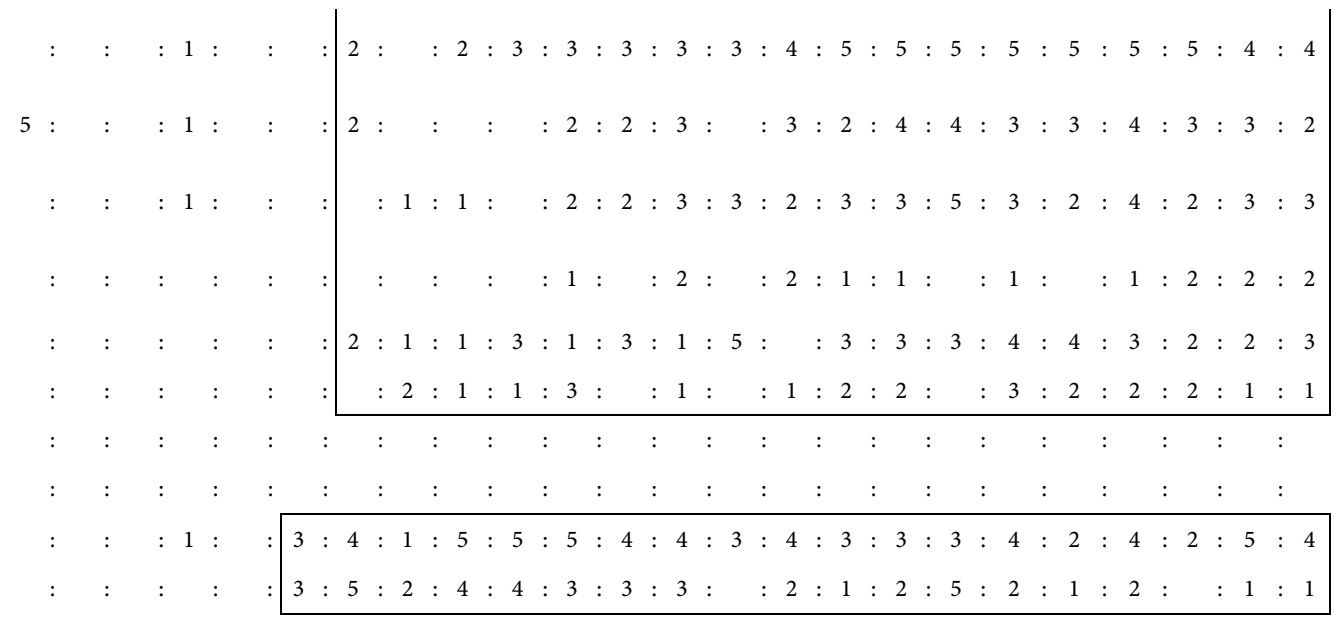

\begin{tabular}{|c|c|c|c|c|c|c|c|c|c|c|c|c|c|c|c|c|c|c|c|c|c|c|c|c|c|c|c|c|c|c|c|c|c|}
\hline & : & : & : & & : & : & & : & : & & : & : & & : & : & 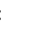 & : & & & : & & : & & : & & : & & : & & & : & & : \\
\hline 3 & $: 2$ & : & : & 2 & : & & 1 & $: 2$ & & 3 & $: 3$ & & 2 & $: 5$ & ; : & : & $:$ & 4 & 5 & & 4 & & 5 & & 4 & : & 4 & & 4 & 3 & & 5 & : \\
\hline & : & : & : & 2 & $:$ & & : & $: 1$ & $:$ & 1 & : 2 & & 2 & $: 2$ & : : & : & $: 2$ & 2 & 2 & & 1 & & 2 & : & 2 & : & 1 & : & 1 & 1 & : & 1 & $: \quad 1$ \\
\hline 3 & : & : & : & 1 & $:$ & & : & $: 1$ & & 3 & $: 2$ & : & & $: 3$ & : & : & $: 2$ & 2 & 2 & & 3 & & 3 & : & 1 & : & 2 & : & 2 & 1 & & 1 & : \\
\hline 3 & $: \quad 1$ & : & : & & $:$ & & : & : & : & & $: 2$ & & 2 & $: 2$ & & : 3 & $: 2$ & 2 & 4 & & 3 & & 1 & & 3 & : & 3 & : & 2 & 1 & : & 2 & $: \quad 1$ \\
\hline & $: 2$ & : & : & & : & : & : & : & : & & $: 1$ & $:$ & & $: 1$ & $1:$ & & : & & & & 1 & : & & : & & : & 1 & : & 1 & & & 1 & : \\
\hline & $: 2$ & : & : & & : & & : & : & : & & $: 2$ & : & & $: 3$ & 3 & & $:$ & 1 & & & 3 & & 3 & : & 1 & : & 1 & : & 1 & 2 & : & 2 & $: 3$ \\
\hline
\end{tabular}

:

Cissus aralioides (Welw. ex Baker) Planch.

Dioscorea minutiflora Engl.

Microcos conocarpoides Burret

Erythrophleum ivorense A.Chev.

Culcasia scandens P.Beauv.

Manilkara sp. 1

Vepris gossweileri (I.Verd.) Mziray 


\section{Continued}

Trichoscypha oddonii De Wild.

Ardisia staudtii Gilg

Rauvolfia caffra Sond.

Macaranga species

Adenia cissampeloides (Planch. ex Hook.) Harms

Syzygium rowlandii Sprague

Dorstenia psilurus Welw. var.

psilurus

Sabicea venosa Benth.

Sherbournia bignoniifolia Hua

Aphanocalyx species

Strychnos icaja Baill.

Fernandoa adolfi-friderici (Gilg \& Mildbr.) Heine

Palisota thollonii Hua

Bikinia letestui (Pellegr.) Wieringa subsp. mayombensis

Aubrevillea species

Berteria species

Staudtia gabonensis Warb. var. macrocarpa

Baillonella toxisperma Pierre

Nephtytys poissonii (Engl.) N.E.Br.

Antrocaryon klaineanum Pierre

Dictyophleba ochracea(K.Schum. ex Hallier f.) Pichon

Maesopsis eminii Engl.

Dracaena acaulis Baker

Hannoa klaineana Pierre

Paulinia pinnata var.pinnata

Cleistanthus species

Geophila obvallata Didr. subsp.

obvallata

Cola species

Psychotria densinervia (K. Krause) Verdc.

Allophylus africanus P.Beauv.

Rauvolfia macrophylla P.Beauv.

Lygodium smithianum C.Presl. ex Kuhn

Urera trinervis (Hochst.) Friis \&

Immelman

Ficus species

Cuviera angolensis vel. sp. aff.

Welw. ex K. Schum.

Cissus leonardii Dewit

Uncaria africana G.Don var. hydrophila

Dalbergia louisii Cronquist

Continued 


\section{Continued}

Phyllanthus species

Impatiens niamniamensis Gilg

Coletocoema dewevrei

Pauridiantha callicarpoides

(Hiern) Bremek.

Triplotaxix stellulifera (Benth.) Hutch.

Baphia species

Strychnos aculeata Soler.

Megaphrynium macrostachyum (K.Schum.) Milne-Redh.

Landolphia owariensis P.Beauv.

Nauclea pobeguinii (Pobéguin ex Pellegr.) Petit

Vismia species

Croton sylvaticus Hochst.

Rhabdophyllum welwitschii Tiegh.

Pausinystalia johimbe (K.Schum.) Pierre ex Beille

Amphimas pterocarpoides Harms

Bambusa vulgaris Schrad. ex J.C.Wendl.

Eremospatha hookeri (G.Mann. \& H. Wendl.) H.Wendl.

Calopogonium mucunoides Desv.

Cayratia debilis (Baker) Suess.

Pennisetum polystachyon Schult.

Andropogon gabonensis Stapf

Clerodendron volubile P.Beauv.

Digitaria polybotrya Stapf

Diodia scandens Sw.

Hyparrhenia diplandra (Hack.)

Stapf

Dichrostachys cinerea (L.) Wight \& Arn.

Imperata cylindrica (L.) Raeusch

Mucuna pruriens (L.) DC.

Vetiveria nigritana (Benth.) Stapg

Nephrolepis undulata (Afz. ex Sw.)

J.Sm.

Milicia excelsa (Welw.) C.Berg

Millettia versicolor Welw. Ex

Baker

Millettia griffoniana Baill.

Morinda species

Sabicea mildbraedii Wernham

Desmodium triflorum (L.) DC.

Millettia comosa (Micheli)

Hauman

Eriosema parviflorum E.Mey.

subsp. parviflorum 


\section{Continued}

Paspalum scrobiculatum L. var. scrobiculatum

Leptoderris congolensis (De Wild.) Dunn

Cleome spinosa Jacq.

Cyperus tenuiculmis Boeck.

Gleichenia linearis (Burm. f.) C.B. Clarke

Dicranopteris linearis (Burm. f.) Underw.

Vigna gracilis (Guill. \& Perr.) Hook.f.

Nymphaea lotus L.

Costus dubius (Afzel.) K.Schum.

Cyperus dives Delile

Clappertonia ficifolia (Willd.)

Decne.

Hydrocharis chevalieri (De Wild.)

Dandy

Asystasia gangetica (L.)

T.Anderson

Centella asiatica (L.) Urb.

Nymphaea nouchali Burm.f.

Psophocarpus palustris Desv.

Sauvagesia erecta L.

Tetracera alnifolia Willd.

Gaertnera paniculata Benth.

Tabernaemontana eglandulosa Stapf

Cephaelis peduncularis Salisb.

Homalium longistaminum $\mathrm{H}$. Perrier

Lipocarpha triceps (Lam.) Nees.

Mikaniopsis tedliei (Oliv. \& Hiern) C.D.Adams

Artabotrys congolensis De Wild. \& T.Durand

Cedronella canariensis (L.) Webb \& Berthel.

Hexalobus crispiflorus A.Rich.

Anopyxis klaineana Pierre

Memecylon species

Anchomanes difformis (Blume) Engl.

Vitex species

Boehmeria platyphylla D.Don

Friesodielsia enghiana (Diels)

Verdc.

Buchnerodendron speciosum

Gürke

Uvaria comperei Le Thomas

Xylopia mildbraedii Diels 


\section{Continued}

Artabotrys thomsonii Oliv.

Discorea semperflorens Uline

Spathandra blakeoides (G. Don) Jacq.-Fél.

Erytrococca chevalieri (Beille)

Prain

Dioscorea preussii Pax

Bertiera loraria N. Hallé

Clerodendron bakeri Gürke

Desplatsia subsericarpa Bocq.

Pteris atrovirens Willd.

Oplismenus hirtellus (L.) P.Beauv

Uvaria scabrida Oliv.

Millettia drastica Welw.

Blighia welwitschii (Hiern) Radlk.

Grewia coriacea Mast.

Lindackeria dentata (Oliv.) Gilg

Ancistrocladus ealaensis J.Leonard

Whitfieldia elongata (P. Beauv.)

C.B. Clarke

Tristemma mauritianum J.F.

Gmel.

Ancylobotrys scandens

(Schumach. \& Thonn.) Pichon.

Paspalum conjugatum P. J. Bergius

Calycobolus heudelotii (Baker ex Oliv.) Heine

Dioscorea praehensilis Benth.

Exellia scamnopetala (Exell)

Boutique

Dalbergia species

Gloriosa superba L.

Vitex ferruginea Schumach. \&

Thonn.

Guibourtia demeusei (Harms) J.Léonard

Loeseneriella apiculata (Welw. ex Oliv.) N.Halle ex R. Wilczek

Baphia leptostemma Baill.

Rinorea bengalensis (Wall.)

O.Ktze.

Xylopia species

Dracaena laxissima Engl.

Cyathea cameruniana Hook.

Hypselodelphys violacea (Ridl.)

Milne-Redh.

Chrysophyllum africanum A.DC.

Landolphia foretiana (Pierre ex Jum.) Pichon

Rinorea elliotii Engl.

Dicellandra barteri Hook.f. var. barteri 


\section{Continued}

Renealmia africana (K.Schum.) Benth.

Cola verticillata (Thonn.) Stapf ex A.Chev.

Rhodognaphalon lukayense (De Wild. \& T.Durand) A.Robyns

Laportea ovalifolia (Schumach.) Chew

Anubias heterophylla Engl.

Costus nudicaulis Bak.

Floscopa mannii C.B.Clarke

Cola lateritia K.Schum.

Leptactina mannii Hook.f.

Aphrostyrax species

Chlamydocola species

Nephtytys afzelii Schott

Pavetta hispidula Wight \& Arn.

Trichilia species

Gilbertiodendron species

Uapaca paludosa Aubrév. \& Léandri

Sterculia species

Salacia species

Thonningia sanguinea Vahl

Warneckia species

Dacryodes igaganga Aubrév. \& Pellegr.

Dracaena species

Schumanniophyton magnificum (K.Schum.) Harms

Lovoa trichilioides Harms

Leptoderris glabrata (Baker) Dunn Leptonychia species

Syzygium giorgii De Wild.

Cyathea species

Artabotrys species

Sterculia dawei Sprague

Maranthes chrysophylla (Oliv.) Prance

Olax latifolia Engl.

Arthropteris palisotii (Desv.)

Alston

Crotonogyne giorgii De Wild.

Diospyros fragrans Gürke

Ataenidia species

Pteris species

Cephaelis batangensis K.Schum.

Rourea species

Olax triplinervia Oliv. 


\section{Continued}

Strychnos afzelii Gilg

Opilia species

Afrobrunnichia erecta (Asch.)

Hutch. \& Dalziel

Paropsia grewioides Welw. ex

Mast.

Dracaena aubryana Brongn. ex E.Morren

Dichapetalum species

Dicranolepis laciniata Gilg

Drypetes laciniata (Pax) Hutch

Rothmannia lateriflora (K.Schum.)

Keay

Argocoffeopsis subcordata (Hiern) Lebrun

Lasiodiscus palustris Figueiredo

Chytranthus species

Costus ligularis Baker

Tessmannia africana Harms

Markhamia tomentosa (Benth.) K. Schum. ex Engl.

Rinorea welwitschii (Oliv.) Kuntze subsp. welwitschii

Diospyros iturensis (Gürke)

Letouzey \& F.White

Marantochloa holostachya (Bak.) Hutch.

Dichapetalum librevillense Pellegr. Dichapetalum lujae De Wild. \& T.Durand

Rothmannia lujae (De Wild.) Keay Nauclea diderrichii (De Wild.) Merr.

Tricalysia breteleri Robbrecht

Rhabdophyllum affine (Hook.f.) Tiegh.

Dichaetanthera species

Dacryodes heterotricha (Pellegr.) H.J.Lam

Olax species

Cleistanthus itsoghensis Pellegr

Afzelia bipindensis Harms

Fillaeopsis discophora Harms

Duguetia confinis (Engl. \& Diels) Chatrou

Entandrophragma angolense (Welw.) C. DC. 
Appendix B. Summary of Associations and Subassociations Identified in the Mayoko Study Area, Republic of Congo. (A = Association; SA = Subassociation)

A1. Nephrolepis biserrata - Elaeis guineensis Anthropogenic Vegetation

A2. Anthocleista schweinfurthii - Musanga cecropioides Degraded Forest and Fern Glades

2.1 Pteridium aquilinum - Anthocleista schweinfurthii - Musanga cecropioides Degraded Forest and Fern Glades

2.2 Harungana madagascariensis - Anthocleista schweinfurthii - Musanga cecropioides Degraded Forest and Fern Glades

A3. Dinophora spenneroides - Selaginella myosurus - Scleria secans Young Secondary Forest

A4. Anthocleista vogelii - Acroceras zizanoides Swamp Forest

4.1 Mucuna flagellipes - Anthocleista vogelii - Acroceras zizanoides Swamp Forest

4.2 Rhynchospora corymbosa - Anthocleista vogelii - Acroceras zizanoides Swamp Forest

4.3 Cyperus pectinatus - Anthocleista vogelii - Acroceras zizanoides Swamp Forest

A5. Berlinia bracteosa - Raphia vinifera Swamp or Riverine Forest

5.1 Gilbertiodendron ogouense - Berlinia bracteosa - Raphia vinifera Swamp or Riverine Forest

5.2 Anthonotha macrophylla - Berlinia bracteosa - Raphia vinifera Swamp or Riverine Forest

A6. Sterculia tragacantha - Agelaea paradoxa Riverine and Temporary Inundated Forest

6.1 Begonia elastostemmoides - Sterculia tragacantha - Agelaea paradoxa Riverine and Temporary Inundated Forest

6.2 Trachyphrynium braunsii - Sterculia tragacantha - Agelaea paradoxa Riverine and Temporary Inundated Forest

A7. Lonchitis currori - Ctenitis protensa Wetland/ Terra firme Transitional Forest

7.1 Ataenidia conferta - Lonchitis currori - Ctenitis protensa Wetland/ Terra firme Transitional Forest

7.2 Acacia kamerunensis - Lonchitis currori - Ctenitis protensa Wetland/ Terra firme Transitional Forest

7.3 Trichilia heudelotii - Lonchitis currori - Ctenitis protensa Wetland/ Terra firme Transitional Forest

A8. Syzygium staudtii - Pseudospondias longifolia degraded Terra firme Forest

8.1 Hymenocardia ulmoides - Syzygium staudtii - Pseudospondias longifolia degraded Terra firme Forest

8.2 Raphia regalis - Syzygium sp. - Pseudospondias longifolia degraded Terra firme Forest 
A9. Scaphopetalum zenkeri - Guaduella oblonga Terra firme Forest on the iron formation

9.1 Geophila repens - Scaphopetalum zenkeri - Terra firme Forest on the iron formation

9.2 Mostuea sp. - Scaphopetalum zenkeri - Guaduella oblonga Terra firme Forest on the iron formation

A10. Greenwayodendron suaveolens - Alchornea floribunda Mature Terra firme Forest on steep slopes

10.1 Strychnos camptoneura - Raphia regalis - Greenwayodendron suaveolens - Alchornea floribunda Mature Terra firme Forest on steep slopes

10.2 Bolbitis gabonensis - Greenwayodendron suaveolens - Alchornea floribunda Mature Terra firme Forest on steep slopes

10.3 Scaphopetalum blackii - Greenwayodendron suaveolens - Alchornea floribunda Mature Terra firme Forest on steep slopes

A11. Guarea cedrata - Celtis adolfi-friderici - Santiria trimera Mature Terra firme Forest

A12. Uapaca guineensis - Aucoumea klaineana Terra firme Forest with degradation

12.1 Celtis adolfi-friderici - Uapaca guineensis - Aucoumea klaineana Terra firme Forest with degradation

12.2 Zanthoxylum heitzii - Uapaca guineensis - Aucoumea klaineana Terra firme Forest with degradation 